\title{
Identification and Characterization of Glucoresponsive Neurons in the Enteric Nervous System
}

\author{
Min-tsai Liu, ${ }^{1,2}$ Susumu Seino, ${ }^{3}$ and Annette L. Kirchgessner ${ }^{1,2}$ \\ ${ }^{1}$ Department of Physiology and Pharmacology, State University of New York Health Science Center at Brooklyn, Brooklyn, \\ New York 11203, 2Department of Anatomy and Cell Biology, Columbia University College of Physicians and Surgeons, \\ New York, New York 10032, and ${ }^{3}$ Department of Molecular Medicine, Chiba University Graduate School of Medicine, \\ 1-8-1, Inohana, Chuo-ku, Chiba 260-8670, Japan
}

\begin{abstract}
We tested the hypothesis that a subset of enteric neurons is glucoresponsive and expresses ATP-sensitive $\mathrm{K}^{+}\left(\mathrm{K}_{\text {ATP }}\right)$ channels. The immunoreactivities of the inwardly rectifying $\mathrm{K}^{+}$channel 6.2 (Kir6.2) and the sulfonylurea receptor (SUR), now renamed SUR1, subunits of pancreatic $\beta$-cell $\mathrm{K}_{\text {ATP }}$ channels, were detected on cholinergic neurons in the guinea pig ileum, many of which were identified as sensory by their costorage of substance $\mathrm{P}$ and/or calbindin. Glucoresponsive neurons were distinguished in the myenteric plexus because of the hyperpolarization and decrease in membrane input resistance that were observed in response to removal of extracellular glucose. The effects of no-glucose were reversed on the reintroduction of glucose or by the $\mathrm{K}_{\text {ATP }}$ channel inhibitor tolbutamide. No reversal of the hyperpolarization was observed when $\mathrm{D}$ mannoheptulose, a hexokinase inhibitor, was present on the reintroduction of glucose. Application of the $\mathrm{K}_{\text {ATP }}$ channel
\end{abstract}

opener diazoxide or the ob gene product leptin mimicked the effect of glucose removal in a reversible manner; moreover, hyperpolarizations evoked by either agent were inhibited by tolbutamide. Glucoresponsive neurons displayed leptin receptor immunoreactivity, which was widespread in both enteric plexuses. Superfusion of diazoxide inhibited fast synaptic activity in myenteric neurons, via activation of presynaptic $\mathrm{K}_{\text {ATP }}$ channels. Diazoxide also produced a decrease in colonic motility. These experiments demonstrate for the first time the presence of glucoresponsive neurons in the gut. We propose that the glucose-induced excitation of these neurons be mediated by inhibition of $\mathrm{K}_{\text {ATP }}$ channels. The results support the idea that enteric $\mathrm{K}_{\text {ATP }}$ channels play a role in glucose-evoked reflexes.

Key words: ATP-sensitive $K^{+}$channels; Kir6.2; SUR1; electrophysiology; diazoxide; tolbutamide; leptin; colonic motility
The hypothalamus plays a pivotal role in the control of feeding behavior and energy homeostasis. It contains neuropeptides that modulate food intake (Inui, 1999), as well as neurons that possess a unique sensitivity to circulating levels of glucose (Oomura, 1983). Neurons that are excited by glucose are found in the ventromedial hypothalamus (VMH) (Ashford et al., 1990a,b). Activation of glucoresponsive neurons inhibits food intake (Anand and Brobeck, 1951).

The pancreatic $\beta$-cell also acts as a glucose sensor with respect to the release of insulin. When blood glucose levels rise, the $\beta$-cell responds to the increase by metabolizing glucose and increasing $[\text { ATP }]_{i}$. The increase in $[\mathrm{ATP}]_{\mathrm{i}}$ closes ATP-sensitive $\mathrm{K}^{+}\left(\mathrm{K}_{\mathrm{ATP}}\right)$ channels present in the $\beta$-cell membrane (Ashcroft et al., 1984; Cook and Hales, 1984; Rorsman and Trube, 1985). This depolarizes the cell (Matthews, 1985), causing the activation of voltagesensitive $\mathrm{Ca}^{2+}$ channels, the influx of $\mathrm{Ca}^{2+}$, and insulin release (Ashcroft and Ashcroft, 1990).

$\mathrm{K}_{\mathrm{ATP}}$ channels are found in glucoresponsive $\mathrm{VMH}$ neurons (Ashford et al., 1990a,b) and in many types of excitable cell where

Received May 25, 1999; revised Aug. 30, 1999; accepted Sept. 14, 1999.

This work was supported by National Institutes of Health Grant NS27645 (A.L.K.), The American Diabetes Association (A.L.K.), and the Ministry of Education, Science, Sports, and Culture, Japan (S.S.). Special thanks to Dr. J. Bryan (Baylor College of Medicine, Houston, TX) for hamster SUR1 cDNA and Theresa Swayne for assistance with confocal microscopy.

Correspondence should be addressed to Dr. Annette Kirchgessner, Department of Physiology and Pharmacology, Box 29, State University of New York Health Science Center at Brooklyn, 450 Clarkson Avenue, Brooklyn, NY 11203. E-mail: akirchgessner@netmail.hscbklyn.edu.

Copyright $\odot 1999$ Society for Neuroscience $\quad 0270-6474 / 99 / 1910305-13 \$ 05.00 / 0$ they act to link cell excitability with metabolic status (Ashcroft and Ashcroft, 1990). $\mathrm{K}_{\text {ATP }}$ channels present in $\beta$-cells are composed of two subunits, the inwardly rectifying $\mathrm{K}^{+}$channel 6.2 (Kir6.2), a member of the Kir family of inwardly rectifying $\mathrm{K}^{+}$ channels, and the sulfonylurea receptor (SUR), now renamed SUR1, a member of the ATP-binding cassette superfamily (Aguilar-Bryan et al., 1995; Inagaki et al., 1995a,b). Sulfonylureas, such as tolbutamide, are blockers of $\mathrm{K}_{\mathrm{ATP}}$ channels, thereby mimicking the actions of high $[\mathrm{ATP}]_{\mathrm{i}}$. The hyperglycemic compound diazoxide opens $\mathrm{K}_{\mathrm{ATP}}$ channels (Dunne et al., 1989; Lee et al., 1999). $\mathrm{K}_{\mathrm{ATP}}$ channels are also regulated by the ob gene product leptin. Leptin activates $\mathrm{K}_{\mathrm{ATP}}$ channels in $\beta$-cells (Keiffer et al., 1997) and VMH neurons (Spanswick et al., 1997), an action consistent with the suppression of insulin secretion (Keiffer et al., 1997) and an action that may reflect its antiobesity actions.

Glucose evokes enteric (Raybould and Zittel, 1995) and enteropancreatic (Kirchgessner et al., 1996) reflexes; however, the mechanism by which glucose is "sensed" in the lumen and how it evokes neurally mediated reflexes are not known. It has been shown that intestinal vagal and spinal afferent nerves are sensitive to glucose (Mei, 1978; Grundy and Scratcherd, 1989). Nerve terminals in the mucosa also originate from primary afferent neurons located within the enteric nervous system (ENS) (Kirchgessner et al., 1992; Furness et al., 1998); however, it is not known whether intrinsic primary afferent neurons are glucoresponsive.

In the present study, we determined whether glucose modulates the activity of enteric neurons and whether enteric neurons express $\mathrm{K}_{\mathrm{ATP}}$ channels. We report that a subset of enteric neurons 
that have been demonstrated previously to be sensory are glucoresponsive, display immunoreactivities of Kir6.2 and SUR1, and are responsive to leptin. These findings are consistent with the idea that enteric neurons contain $\mathrm{K}_{\mathrm{ATP}}$ channels and support the possibility that enteric $\mathrm{K}_{\mathrm{ATP}}$ channels play a role in glucoseevoked reflexes.

\section{MATERIALS AND METHODS}

Immunocytochemistry. Male guinea pigs (200-300 gm) were stunned by a blow to the head and exsanguinated. The Animal Care and Use Committee of Columbia University has approved this procedure. The bowel and pancreas were removed and washed with Krebs' solution. For wholemount preparations, segments of gut were washed through the lumen with iced Krebs' solution and cut along the mesenteric border. The resulting sheet of gut was pinned flat, mucosal side up, in Krebs' solution in a silicone elastomer (Sylgard; Dow Corning, Midland, MI)-coated dish. The immobilized tissue was fixed for $3.0 \mathrm{hr}$ with $4 \%$ paraformaldehyde in $0.1 \mathrm{M}$ phosphate buffer, $\mathrm{pH}$ 7.4. After fixation, the preparations were washed in PBS for $1 \mathrm{hr}$ and then dissected into layers, as described previously (Kirchgessner and Gershon, 1988). Material to be sectioned was cryoprotected overnight $\left(\right.$ at $\left.4^{\circ} \mathrm{C}\right)$ in PBS containing $30 \%(\mathrm{w} / \mathrm{v})$ sucrose, embedded in ornithine carbamyl transferase (TissueTek; Miles, Elkhart, IN), frozen with liquid $\mathrm{N}_{2}$, and sectioned $(10 \mu \mathrm{m})$ by the use of a cryostat microtome.

To locate $\mathrm{K}_{\text {АTP }}$ channel and leptin receptor proteins in the tissue by immunocytochemistry, we exposed free-floating preparations or cryostat sections to PBS containing $0.5 \%$ Triton X-100 and $4 \%$ horse serum for 30 min to permeabilize the tissue and reduce background staining. Immunoreactivity was then demonstrated by incubating the tissues with affinity-purified polyclonal antibodies $\left(24-48 \mathrm{hr} ; 4^{\circ} \mathrm{C}\right)$ to Kir6.2, SUR1, or leptin receptors (LepR). The primary Kir6.2 antiserum used has been described in detail elsewhere (Suzuki et al., 1997). It was raised in rabbits against the synthetic peptide corresponding to the $14 \mathrm{C}$-terminal amino acid residues (KAKPKFSISPDSLS) of mouse origin. The SUR1 antibody was raised in rabbits against the synthetic peptide KPEKLLSOKDSVFASFVRADK that corresponds to amino acid residues 1561-1581 at the C-terminal of rat SUR1. Antibody screening was done by ELISA on plates coated with the immunizing peptide. The antibody was purified by immunoaffinity chromatography. Further characterization was performed by Western blot analysis using crude membrane fractions of COS-1 cells stably transfected with pCMV6C carrying hamster SUR1 or vector alone (control) or crude membrane fractions of MIN6 cells. COS-1 cells were transfected by the lipofectamine method (Inagaki et al., 1995b), and electroblotting and signal detection, using an enhanced chemiluminescence system (ECL; Amersham, Arlington Heights, IL), were performed as described previously (Suzuki et al., 1997). An absorption test was performed by preincubating anti-SUR1 antibody with $2.4 \mathrm{mg} / \mathrm{ml}$ antigen oligopeptides.

Antiserum against LepR was purchased from Santa Cruz Biotechnology (diluted 1:100; Santa Cruz, CA). This antibody is an affinity-purified goat polyclonal antiserum raised against a peptide corresponding to amino acids 877-894 mapping at the $\mathrm{C}$ terminal of LepR of mouse origin. This antiserum has been tested extensively (Hakansson et al., 1998; Horvath et al., 1999) and was found to bind to both the short and long isoforms of LepR in transfected cells and rat hypothalamus. Bound antibodies were visualized by incubating tissues for $3 \mathrm{hr}$ with fluorescein isothiocyanate (FITC)-labeled secondary antibodies to rabbit or goat IgG (diluted 1:200; Jackson ImmunoResearch, West Grove, PA). After washing with PBS, the tissues were coverslipped with Vectashield (Vector Laboratories, Burlingame, CA). In every experiment, parallel control sections were included that were incubated with normal horse serum instead of primary antibodies. Omission of the primary antisera resulted in no staining. FITC fluorescence was viewed with a Chroma Optical filter set (excitation, $480 \pm 15 \mathrm{~nm}$; dichroic, $505 \mathrm{~nm}$; emission, $535 \pm 20 \mathrm{~nm}$ ).

Double-label immunocytochemistry was used to identify cells that display Kir6.2, SUR1, and LepR immunoreactivity. When double-label immunocytochemistry was performed, one antigen (Kir6.2, SUR1, or LepR) was visualized with a species-specific secondary antibody coupled to FITC, whereas the second antigen was located with a species-specific secondary antibody coupled to indocarbocyanine (Cy3; diluted 1:2000; Jackson ImmunoResearch). Reagents used to locate antigens simultaneously with $\mathrm{K}_{\mathrm{ATP}}$ channel or LepR immunoreactivity included a monoclonal antibody to calbindin (diluted 1:100; Sigma, St. Louis, MO) (Kirchgessner and Liu, 1999) and polyclonal antibodies to substance P
(SP; diluted 1:2000; Accurate Chemicals, Westbury, NY) (Kirchgessner and Liu, 1999), c-Kit (diluted 1:1000; Santa Cruz Biotechnology), 5-hydroxytryptamine (5-HT; diluted 1:400; Accurate Chemicals) (Kirchgessner et al., 1992), choline acetyltransferase (ChAT; diluted 1:1000; Chemicon, Temicula, CA) (Kirchgessner and Liu, 1998), cholecystokinin (CCK; diluted 1:1000; Chemicon), and neuropeptide Y (NPY; diluted 1:1000; Peninsula Laboratories, Belmont, CA) (Kirchgessner et al., 1992). Omission of the primary antisera resulted in no staining. Cy3 fluorescence was visualized by vertical fluorescence microscopy using a Chroma Optical filter set (excitation, $540 \pm 12.5 \mathrm{~nm}$; dichroic, $565 \mathrm{~nm}$; emission, $605 \pm 27.5 \mathrm{~nm}$ ). There is no cross-detection between the FITC- and Cy3-selective filter sets.

Confocal microscopy. Preparations were examined by the use of an LSM 410 Laser Scanning Confocal Microscope (Zeiss, Thornwood, NY) equipped with a krypton/argon laser and attached to a Zeiss Axiovert $100 \mathrm{TV}$ microscope. Usually, $10-15$ optical sections were taken at $0.5-1.0$ $\mu \mathrm{m}$ intervals. Images of $1012 \times 1012$ pixels were obtained and modified by the use of Adobe Photoshop 3.0 (Adobe Systems, Mountain View, CA) to adjust their contrast and brightness. Images were printed using a dye sublimation printer (Tektronix Phaser 440 for color prints; Kodak XLS-8600 for black-and-white prints; Eastman Kodak, Rochester, NY).

Electrophysiology. Male guinea pigs (200-300 gm) were stunned and exsanguinated. A segment of ileum was excised and placed in oxygenated $\left(95 \% \mathrm{O}_{2} / 5 \% \mathrm{CO}_{2}\right)$ Krebs' solution of the following composition (mM): $\mathrm{NaCl}$ (121), $\mathrm{KCl}$ (5.9), $\mathrm{CaCl}_{2}$ (2.5), $\mathrm{NaHCO}_{3}$ (14.3), $\mathrm{NaH}_{2} \mathrm{PO}_{4}$ (1.3), $\mathrm{MgCl}_{2}$ (1.2), and glucose (12.7). The Krebs' solution contained nifedipine $(1.0 \mu \mathrm{M})$ and scopolamine $(1.0 \mu \mathrm{M})$ to block longitudinal muscle contractions while intracellular recordings were obtained. When glucose was removed from the Krebs' solution, it was replaced with $\mathrm{NaCl}$ to maintain osmolarity (Jiang and Haddad, 1992; Calabresi et al., 1997). A $1.0 \mathrm{~mm}^{2}$ segment of ileum was cut open and pinned (mucosal surface up) in a dish coated with a silicone elastomer. Preparations of longitudinal muscle with adherent myenteric plexus were dissected, transferred to a recording chamber (volume $=1.0 \mathrm{ml}$ ), and stretched lightly with stainless steel pins. Preparations were superfused $\left(3.0 \mathrm{ml} / \mathrm{min} ; 36^{\circ} \mathrm{C}\right)$ with oxygenated Krebs' solution. Myenteric ganglia were visualized on the stage of a Zeiss (Axiovert 35) inverted microscope at a magnification of $200 \times$. Intracellular recordings were obtained from neurons using glass microelectrodes filled with $2.0 \mathrm{M} \mathrm{KCl}$ (tip resistance, 80-140 M $\Omega$ ) (Liu et al., 1997). A negative-capacity compensation amplifier (Axoclamp 2B) was used to record the transmembrane potential difference and to inject current via the recording electrode. Rectangular electrical current pulses with a duration of $40-400 \mathrm{msec}$ were injected through the microelectrode and were driven by Grass S88 stimulators (Grass Instruments, Quincy, MA). Satisfactory impalements resulted in a stable resting membrane potential of $-35 \mathrm{mV}$ or more. The input resistance of the impaled cell was determined after the injection of a 0.1-0.9 nA hyperpolarizing current pulse (40-100 msec duration). Membrane potentials and intracellular current injections were displayed on a digital storage oscilloscope (DSO450; Gould, Cleveland, $\mathrm{OH}$ ), and permanent records were made on a thermal array chart recorder (TA240; Gould).

Synaptic activation of neurons was elicited by direct stimuli applied to nerve trunks attached to a myenteric ganglion with monopolar extracellular electrodes made from Teflon-insulated platinum wire $(25 \mu \mathrm{m}$ diameter). To evoke a fast EPSP, we stimulated nerve fibers using single stimuli of $0.5 \mathrm{msec}$ duration applied at a rate of $0.2 \mathrm{~Hz}$. When studying fast EPSPs, four individual responses were averaged. Krebs' solution with tetrodotoxin (TTX) or with an elevated concentration of $\mathrm{Mg}^{2+}(15$ $\mathrm{mM})$ and deficient in $\mathrm{Ca}^{2+}(0.1 \mathrm{mM})$ was used to block synaptic transmission. Data are expressed as means \pm SEM. ANOVA followed by the Scheffe $F$ test (StatView 4.5; Abacus Concepts, Calabasas, CA) was used to test for significance $(p<0.001)$.

Drugs were applied to neurons by addition to the fluid superfusing the preparations; complete exchange of the solution in the recording chamber took 2 min. The drugs used were the following: (1) from Sigma, sodium azide and TTX; (2) from Indofine Chemical Company (Somerville, NJ), D-mannoheptulose; (3) from Research Biochemicals (Natick, MA), diazoxide, tolbutamide, and pinacidil; and (4) from Biomol (Plymouth Meeting, PA), human recombinant leptin. Tolbutamide was made up as a $500 \mathrm{~mm}$ stock solution in dimethyl sulfoxide, whereas diazoxide was prepared as a $300 \mathrm{~mm}$ solution in $0.1 \mathrm{M} \mathrm{NaOH}$. Both compounds were diluted at least 1000 times before tissue application. Human recombinant leptin was prepared as a $125 \mu \mathrm{M}$ stock solution and diluted daily to the concentrations required (10-100 nM) in Krebs' solution containing $0.01 \%$ BSA. Superfusion of the drug vehicle at relevant concentrations 
did not have any measurable effect on the electrical properties of enteric neurons.

Intracellular labeling with Neurobiotin. To identify the enteric neurons from which recordings were made, in some experiments, impaled neurons were filled with $2.0 \%$ Neurobiotin (Vector Laboratories) in $1.0 \mathrm{M}$ $\mathrm{KCl}$, as reported previously (Liu et al., 1997). After impaled neurons had been characterized electrophysiologically, a depolarizing current was passed through the microelectrodes $(0.4-0.6 \mathrm{nA} ; 200 \mathrm{msec}$ for $25 \mathrm{~min})$ to inject the Neurobiotin. After dye injection, the preparations were fixed and permeabilized, as described above. Preparations were then incubated with streptavidin (Jackson ImmunoResearch; 1:1000) conjugated to Cy3 for $1 \mathrm{hr}$.

Colonic motility assay. Colonic motility was measured according to established methods (Foxx-Orenstein and Grider, 1996; Wade et al., 1996). Briefly, segments of guinea pig distal colon $(\sim 8 \mathrm{~cm}$ long) were mounted in Sylgard-coated chambers with insect pins placed in the mesentery. The preparations were perfused $(10 \mathrm{ml} / \mathrm{min})$ continuously with oxygenated Krebs' solution and maintained at $37^{\circ} \mathrm{C}$. Preparations were allowed to equilibrate and empty themselves of fecal pellets for $\sim 30$ min before the experiments were begun. A baseline rate of motility was then determined.

To evoke the peristaltic reflex, we inserted an artificial fecal pellet, made from Sylgard or modeling clay, into the oral end of the isolated segments of colon. The pellets were approximately the same size and shape as a fecal pellet. The rate at which the pellet was transported distally was measured by determining the time taken by the pellet to transverse a distance of $5 \mathrm{~cm}$ in the middle of the segment. The pellet was allowed to complete its passage down the entire segment. The pellet was then retrieved and reinserted at the oral end of the segment of colon. Experiments were started when the rate of propulsion became almost constant for three consecutive trials after 1 min intervals. The average rate of propulsion measured for the three consecutive trials counted as the control rate. Diazoxide was added after the control records were obtained. The colon was incubated for $10 \mathrm{~min}$ in the presence of the compound before resuming the measurement of the rate of propulsion of the pellets. The peristaltic reflex was again quantified by averaging the rate of propulsion for three consecutive trials. The rate of propulsion of the pellet in the presence of diazoxide was expressed as a percentage of the control rate. Each preparation thus served as its own control. Comparisons between means for different concentrations of diazoxide were analyzed using ANOVA followed by the Scheffe $F$ test $(p<0.001)$.

\section{RESULTS}

\section{$\mathrm{K}_{\mathrm{ATP}}$ channel subunit immunoreactivity is displayed by enteric neurons}

If $\mathrm{K}_{\mathrm{ATP}}$ channels were present in the ENS, then as in other sites where $\mathrm{K}_{\mathrm{ATP}}$ channels exist, the enteric plexuses would be expected to contain neurons that can be demonstrated with $\mathrm{K}_{\mathrm{ATP}}$ channel-selective antibodies. Recent studies have shown that the $\mathrm{K}_{\text {ATP }}$ channels found in $\beta$-cells are formed by the molecular interaction between an inwardly rectifying $\mathrm{K}^{+}$channel subunit (Kir6.2) (Inagaki et al., 1995a; Sakura et al., 1995) and a highaffinity receptor for the sulfonylureas (SUR1) (Inagaki et al., 1995a). Immunocytochemistry was thus used to determine whether evidence of the expression of these $\mathrm{K}_{\mathrm{ATP}}$ channel subunits could be obtained.

The immunoreactivities of both Kir6.2 (Fig. 1 $A-E$ ) and SUR1 (Fig. $1 F, G$ ) were detected on neurons in the guinea pig ileum. In general, immunolabeling was punctate, filling the perikarya and, occasionally, the proximal dendrites of a subset of enteric neurons (Fig. $1 D$ ). In addition, the staining intensity of somata varied (Fig. $1 A)$. Some were very intensely stained; others were more lightly stained.

Neurons in both the submucosal (Fig. $1 A, B$ ) and myenteric (Fig. $1 D$ ) plexus that displayed ChAT immunoreactivity expressed Kir6.2 and SUR1; therefore, $\mathrm{K}_{\mathrm{ATP}}$ channels appear to be expressed by cholinergic neurons. Submucosal Kir6.2- and SUR1immunoreactive neurons also displayed SP immunoreactivity (Fig. $1 C$ ), and a subset contained the $\mathrm{Ca}^{2+}$-binding protein calbindin (Fig. $1 F, G$ ), markers of submucosal primary afferent neurons (Kirchgessner et al., 1992). The majority $(82.73 \pm 1.3 \%)$ of calbindin-immunoreactive neurons $(n=250$ cells from four preparations) in the myenteric plexus contained Kir6.2, and $75.0 \pm 3.1 \%$ ( $n=200$ cells from four preparations $)$ contained SUR1. Calbindin is present in $\sim 70 \%$ of type $2 / \mathrm{AH}$ myenteric neurons (Iyer et al., 1988) and is a marker of primary afferent neurons in the myenteric plexus (Furness et al., 1998). Kir6.2 or SUR1 was also found on neurons that did not display calbindin immunoreactivity (Fig. $1 E$ ). These cells displayed Dogiel type I morphology, characteristic of enteric motor and/or interneurons (Costa et al., 1996).

Kir6.2- and SUR1-immunoreactive nerve fibers were found in each plexus. Punctate immunoreactivity was found on nerve fibers in interganglionic connectives and in enteric ganglia (Fig. $1 A$ ). Immunoreactive axons were also observed in the mucosa, where they encircled intestinal crypts (Fig. $1 H$ ), in the circular muscle layer (Fig. 1I), and in paravascular nerve bundles (data not shown). Kir6.2 immunoreactivity was found on smooth muscle cells (data not shown). Cells in the deep muscular plexus (Fig. 1I) displayed SUR1 immunoreactivity. These cells were identified as interstitial cells of Cajal, by the presence of c-Kit immunoreactivity (Fig. 1I, inset) (Komuro and Zhou, 1996).

As demonstrated previously in the mouse pancreas (Suzuki et al., 1997), Kir6.2 immunoreactivity was found in guinea pig islets (Fig. 2A). Immunoreactivity was punctate (Fig. 2A, inset) and appeared to be associated with the secretory granules of insulinimmunoreactive islet cells (data not shown). The localization of SUR1 immunoreactivity in islet cells was similar to that of Kir6.2 (Fig. 2B). Kir6.2 immunoreactivity was also found in a subset of cholinergic pancreatic neurons (Fig. 2C,D) and cholinergic nerve fibers (Fig. $2 E, F$ ) in the pancreatic parenchyma.

Incubation of sections from pancreas or ileum with SUR1 antiserum preabsorbed with control peptide abolished all immunoreactivity (Fig. $2 G$ ). By the use of anti-SUR1 antibody, a single band at $140 \mathrm{kDa}$ was detected in the crude membrane fractions of COS-1 cells transfected with hamster SUR1 (Fig. 2H, lane 2), whereas no signal was detected in COS-1 cells transfected with pCMV vector alone (Fig. 2H, lane 1). A $140 \mathrm{kDa}$ band was also detected in crude membrane fractions of the mouse insulinsecreting cell line MIN6 (Fig. 2H, lane 3). Together with the results of immunocytochemistry (see above), these findings establish the specificity of the SUR1 antibodies.

\section{Glucoresponsive neurons are present in the ENS}

Intracellular records were obtained from guinea pig myenteric neurons (Liu et al., 1997) to determine whether, as the immunocytochemical data outlined above suggest, these cells express $\mathrm{K}_{\text {ATP }}$ channels. Cells were classified physiologically as 2/AH or 1/S according to established criteria (Schutte et al., 1995; Liu et al., 1997). To reduce the intracellular ATP concentration within the cell soma to levels at which $\mathrm{K}_{\mathrm{ATP}}$ channels could open spontaneously, we perfused preparations with a glucose-free solution.

Forty-seven of $61(77 \%)$ myenteric neurons responded to the removal of glucose $(12.7 \mathrm{~mm})$ from the perfusing medium with a change in resting membrane potential (RMP), often with a change in neuronal input resistance. Sixty-two percent were identified as glucoresponsive by virtue of the hyperpolarization that was observed in response to removal of extracellular glucose (Fig. $3 A$ ). Thirty-eight percent were identified as glucosensitive, because application of a glucose-free solution evoked a membrane 


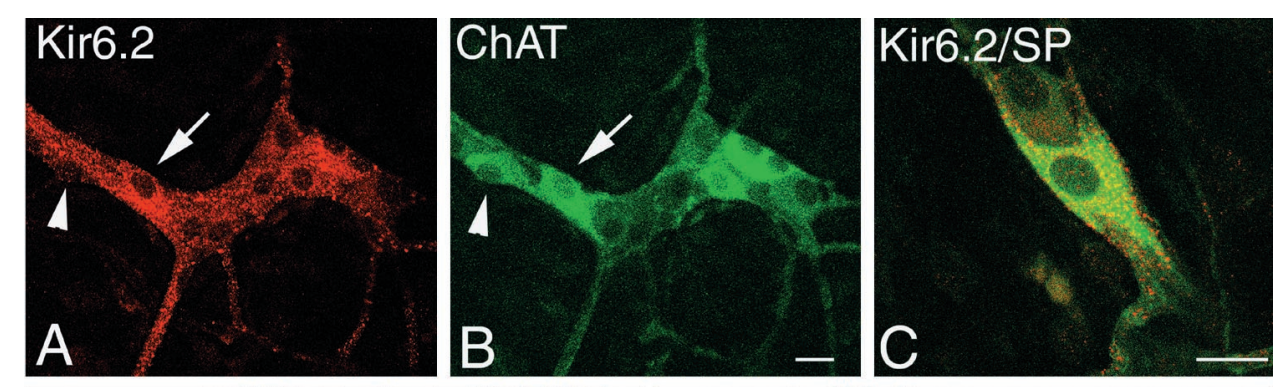

Figure 1. Kir6.2 channel- and SUR1-like immunoreactivity in the guinea pig ileum. $A, B$, A subset of Kir6.2-immunoreactive neurons in the submucosal plexus $(A ;$ arrow) coexpress ChAT $(B)$. A subset of ChAT neurons do not express Kir6.2 (arrowhead). $C$, Kir6.2 (red) is displayed by SP-immunoreactive neurons (green) in the submucosal plexus. Doubly labeled cells appear yellow. D, Kir6.2 (red) is displayed by ChAT-immunoreactive neurons (green) in the myenteric plexus. Kir6.2 immunoreactivity is present in the cell soma and proximal dendrites (arrow). E, Not all calbindin $(C B P)$-immunoreactive neurons ( green) in the myenteric plexus express Kir6.2 (red; arrow). $F, G$, SUR1-immunoreactive submucosal neurons $(F)$ contain calbindin $(G)$. $H$, SUR1-immunoreactive nerve fibers encircle mucosal crypts (arrow). I, SUR1immunoreactive fibers found in the circular muscle layer $(\mathrm{cm})$ are deep muscular plexus (arrow). Inset, SUR1 cells in the deep muscular plexus ( green) display c-Kit immunoreactivity (red). $A-E$ are confocal images. Scale bars, $30 \mu \mathrm{m}$.
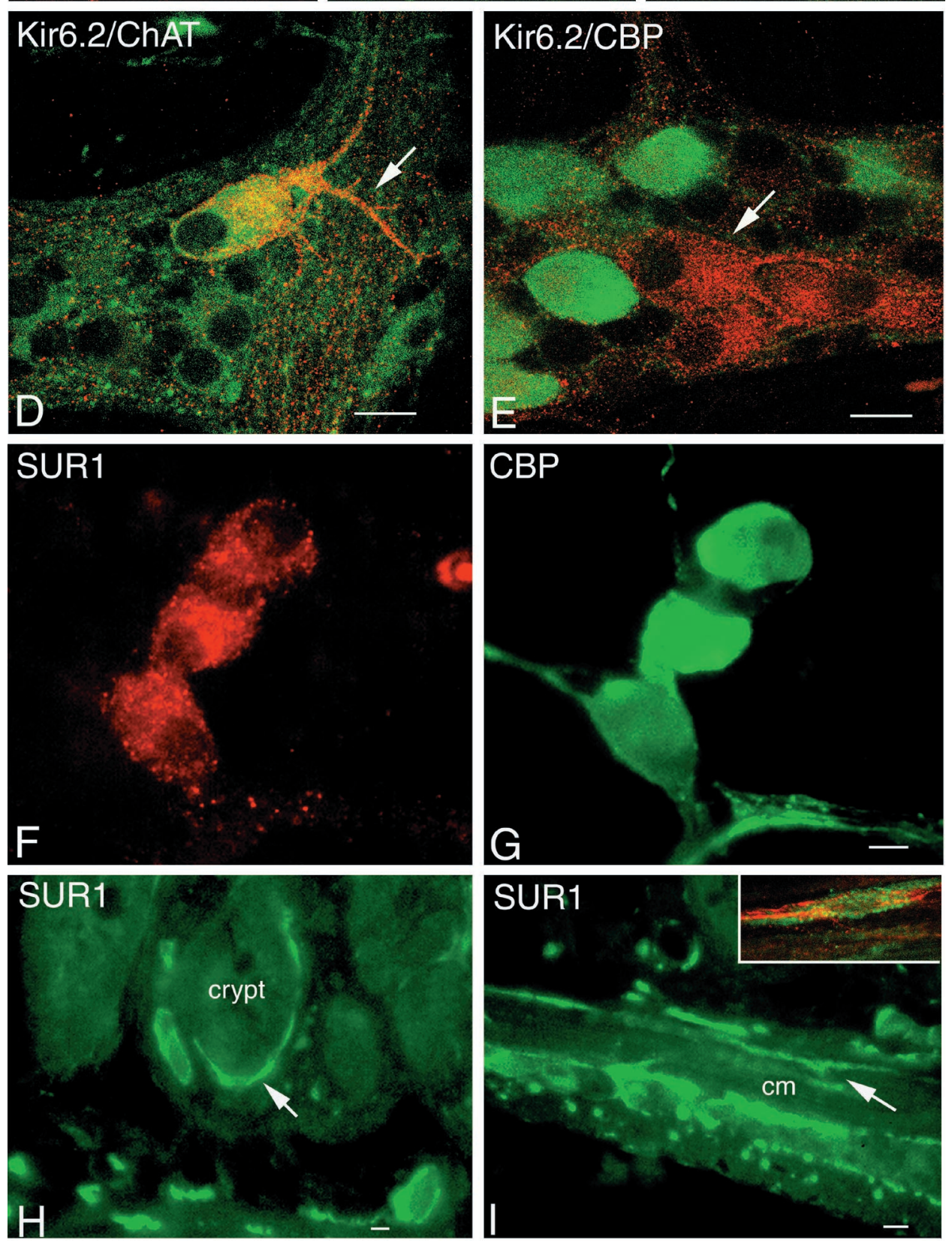

depolarization of up to $5 \mathrm{mV}$ (Oomura et al., 1974). Both 1/S $(33 \%)$ and $2 / \mathrm{AH}(75 \%)$ neurons were hyperpolarized by the removal of glucose, although more such responses were obtained from $2 / \mathrm{AH}$ cells, because they tended to be impaled most often.

Within 10-15 min of glucose removal, the RMP of $2 / \mathrm{AH}$ and $1 / \mathrm{S}$ neurons was significantly increased when compared with the initial value in normal glucose $(12.7 \mathrm{~mm})$-containing Krebs' solu- tion $(8.4 \pm 1.6 \mathrm{mV}$ and $n=19 ; 6.3 \pm 1.8 \mathrm{mV}$ and $n=5$, respectively; $p<0.01)$. In each case, the hyperpolarization was accompanied by a decrease in neuronal input resistance (17.7 \pm $2.8 \%$ and $n=19 ; 5.6 \pm 1.7 \%$ and $n=5$, respectively), measured by changes in response to injection of hyperpolarizing current pulses. Recovery of membrane potential and input resistance to control levels required $\sim 15 \mathrm{~min}$ after washout. At the end of the 

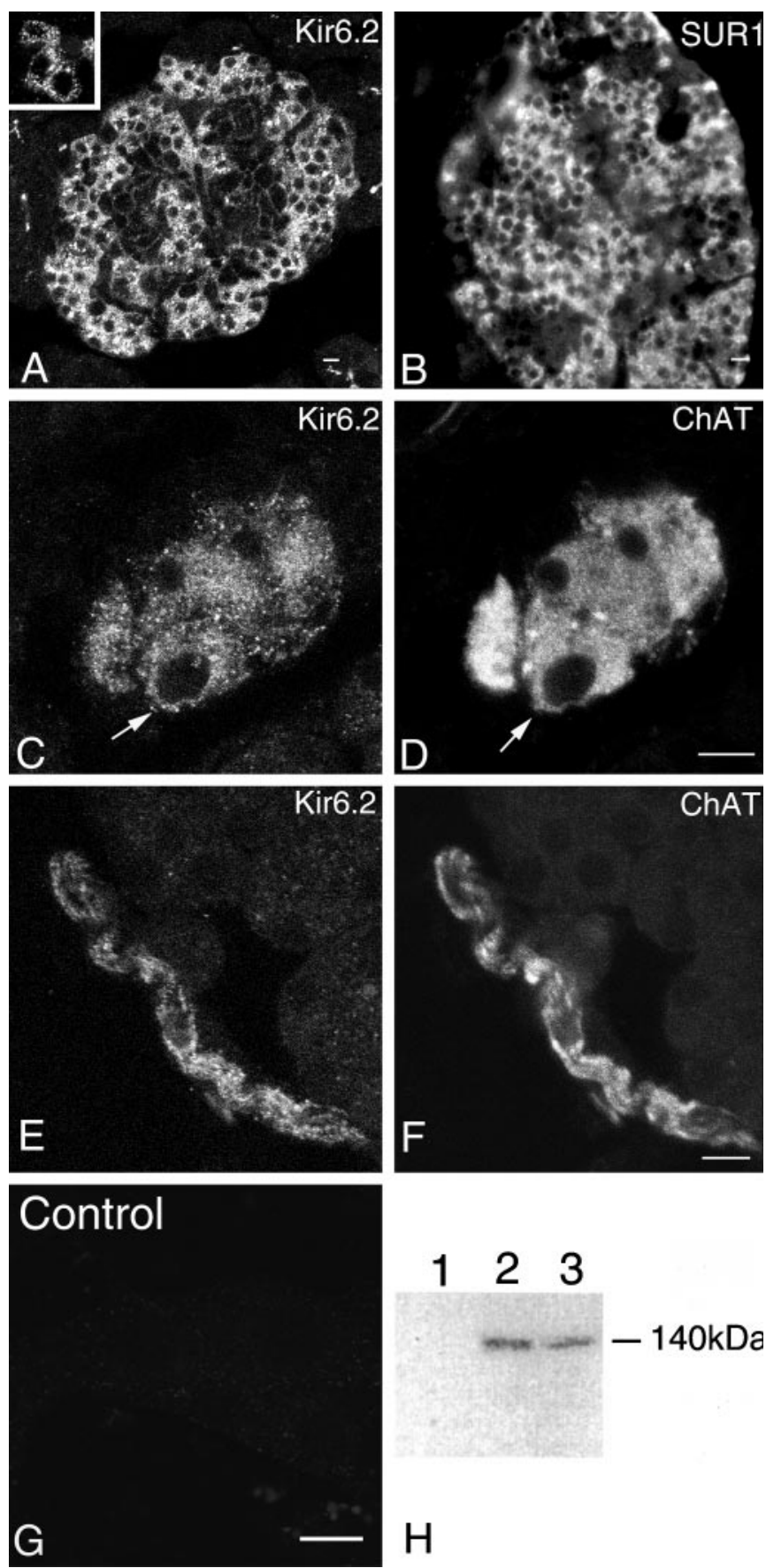

Figure 2. Kir6.2 and SUR1-like immunoreactivity in the guinea pig pancreas. $A, B$, A subset of islet cells display Kir6.2 (A) and SUR1 (B) immunoreactivity. $A$, Inset, Immunoreactivity is localized to secretory granules. $C-F$, Kir6.2 immunoreactivity $(C, E)$ is displayed by ChATpositive pancreatic neurons $(D)$ and nerve fibers $(F)$. $G$, Note the total absence of SUR1 staining in sections incubated with preadsorbed antiserum. $H$, Western blotting of SUR1 is shown. Lane 1, Crude membrane fraction of mock-transfected COS-1 cells is shown; lane 2, crude membrane fraction of COS- 1 cells transfected with pCMV6C vector carrying hamster SUR1 is shown; lane 3, crude membrane fraction of the mouse insulinoma cell line MIN6 is shown. Approximately $5 \mu \mathrm{g}$ of total cell was applied to the lanes, and the plate was treated with SUR1 antibody (diluted 1:4000). The figure reveals a dense band of $\sim 140 \mathrm{kDa}$ in lanes 2 and 3. $A$ and $C-F$ are confocal images. Scale bars: $A-G, 30 \mu \mathrm{m}$. recovery period, in some of the neurons, the membrane input resistance increased slightly beyond control, and excitability, reflected by an increased number of spontaneous spikes, was enhanced. The possibility that the no-glucose-induced potential change was a secondary effect caused by release of neurotransmitters from nerve terminals was tested by superfusion of a no-glucose solution in the presence and absence of TTX $(0.3 \mu \mathrm{M})$. In 2/AH $(n=3)$ and $1 / \mathrm{S}(n=3)$ neurons, the presence of TTX did not significantly alter the hyperpolarization produced by glucose-free solutions; therefore, no-glucose was probably having a direct effect on the neurons.

The dose dependence of the response to glucose was studied in 2/AH neurons. The amplitude of the membrane hyperpolarization was dose dependent (Fig. 3B). A progressive decrease in the concentration of glucose (from $12.7 \mathrm{~mm}$ ) resulted in larger hyperpolarizations, reaching a plateau at $\sim 5 \mathrm{~mm}$. In contrast, higher concentrations of glucose $(16.7 \mathrm{~mm})$ evoked a significant depolarization and increase in input resistance (Fig. 3B).

To examine the ionic currents potentially involved in the noglucose-evoked voltage response, we superfused a glucose-free solution when 2/AH neurons were current clamped at potentials more positive or more negative than the RMP. Plots of currentvoltage relations revealed decreased input resistance during the hyperpolarizing action of no-glucose. The slopes of currentvoltage plots were always decreased relative to control during the membrane hyperpolarization (Fig. $3 C$ ). The mean reversal potential was $-83 \mathrm{mV}$, a value close to the predicted $\mathrm{K}^{+}$equilibrium potential $(-93 \mathrm{mV})$. Because of the reversal potential data and the decrease in input resistance, the no-glucose-evoked hyperpolarization appears to involve the activation of $\mathrm{a} \mathrm{K}^{+}$ conductance.

The hyperpolarization observed in response to removal of extracellular glucose was fully reversed on the readdition of 12.7 mM glucose to the bath solution (Fig. $3 A$ ). If the same protocol was followed but with $12 \mathrm{~mm}$ D-mannoheptulose (an inhibitor of glucose metabolism at the level of hexose phosphorylation) present on readdition of glucose, the cells did not repolarize (Fig. $3 D)$. The actions of glucose and D-mannoheptulose on enteric neurons are similar to those observed in $\beta$-cells and $\mathrm{VMH}$ neurons (Dean et al., 1975; Ashford et al., 1990a) and are consistent with the idea that no-glucose exerts its effects via $K_{A T P}$ channels that have been opened by a decrease in intracellular ATP. In support of this hypothesis, superfusion of the metabolic inhibitor sodium azide $(3 \mathrm{~mm})$ evoked a hyperpolarization $(3.7 \pm$ $0.8 \mathrm{mV})$ in glucoresponsive $2 / \mathrm{AH}$ neurons $(n=6)$, with a concomitant decrease in input resistance $(12.0 \pm 3.6 \%)$. The effect of sodium azide was reversible on washout of the inhibitor.

\section{Glucoresponsive enteric neurons are sensitive to tolbutamide}

The hyperpolarization of enteric neurons produced by glucosefree solutions appears to be caused by the activation of a $\mathrm{K}^{+}$ current. To determine whether the channel that mediates this response is $\mathrm{K}_{\mathrm{ATP}}$, we examined the effects of the sulfonylurea tolbutamide. In seven 2/AH neurons, a glucose-free solution hyperpolarized the membrane potential from -55 to $-68 \mathrm{mV}$ with a concomitant decrease in input resistance of $18.0 \pm 6.2 \%$. Superfusion of tolbutamide $(100-500 \mu \mathrm{M})$ completely reversed the effects of no-glucose (Fig. 4A), inducing depolarization (7.5 \pm $2.1 \mathrm{mV} ; n=7)$ and an increased input resistance $(16.4 \pm 6.9 \%$; $n=7)$. Like VMH neurons (Ashford et al., 1990b), in the presence of tolbutamide and no-glucose, glucoresponsive enteric 


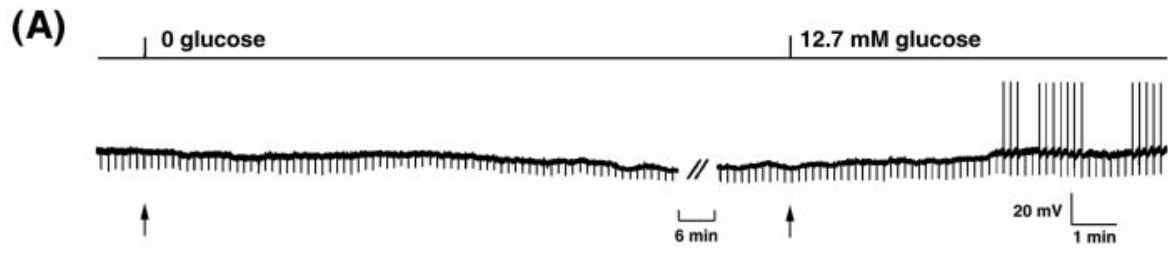

Figure 3. Identification of glucoresponsive neurons in the guinea pig myenteric plexus. $A$, Superfusion of a no-glucose solution (0 glucose) induces a membrane hyperpolarization in a $2 / \mathrm{AH}$ neuron, from an RMP of -53 to $-70 \mathrm{mV}$, that is associated with a decrease in input resistance (reflected by a decline in the amplitude of electrotonic potentials). Note the time breaks in the record indicated by the gaps. $B$, Application of glucose elicited a concentration-dependent change in the RMP $(\mathrm{Vm})$ and input resistance (Rin) of 2/AH neurons. Data are expressed as changes in the amplitude $(\Delta \mathrm{Vm} ; \mathrm{mV})$ and percent change $(\Delta R \mathrm{in} ; \%)$ of the maximum control response $(n=6)$ in the presence of $12.7 \mathrm{~mm}$ glucose. $C$, The current-voltage relation obtained in the presence of glucose $(12.7 \mathrm{~mm}$; control) and no-glucose is shown. The mean reversal potential associated with the increase in conductance was $-83 \mathrm{mV}$. $D$, Inhibition of glucose metabolism by D-mannoheptulose $(12 \mathrm{~mm})$ prevents the repolarization in $2 / \mathrm{AH}$ neurons. RMPs (indicated by the dashed line in $D$ ) for cells were $-53 \mathrm{mV}(A)$ and $-61 \mathrm{mV}(D)$.

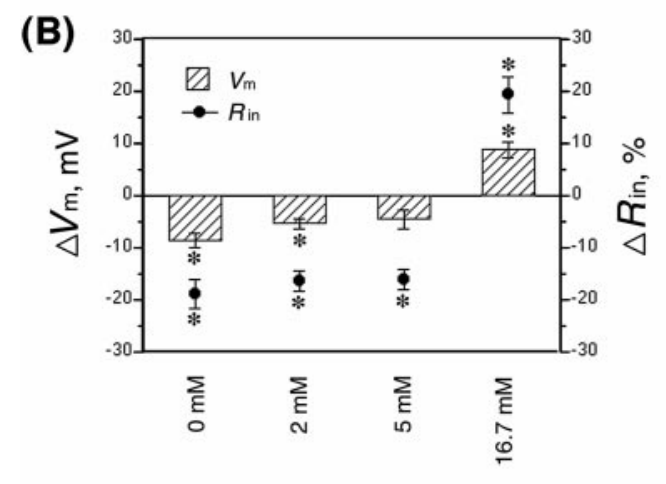

(C)

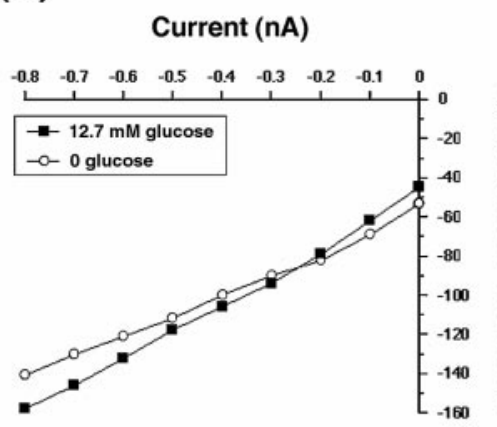

(D)

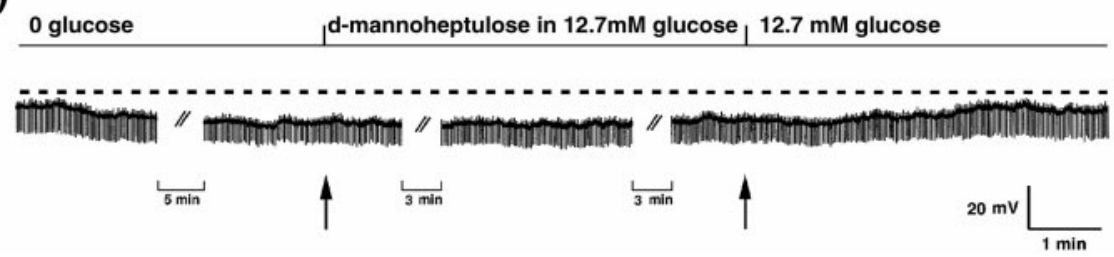

neurons often reached the threshold for action potential firing (Fig. 4A). Removal of tolbutamide allowed the no-glucose response to reemerge, as neurons reestablished a hyperpolarized membrane potential with an associated increased conductance (data not shown). Reducing the extracellular glucose concentration bathing glucoresponsive neurons or applying tolbutamide are considered to alter membrane potential and input resistance by activation and inhibition, respectively, of $\mathrm{K}_{\mathrm{ATP}}$ channels (Ashford et al., 1990a,b); therefore, our data strongly suggest that glucoresponsive neurons express $\mathrm{K}_{\mathrm{ATP}}$ channels.

Interestingly, tolbutamide in the presence of glucose caused a depolarization of $2 / \mathrm{AH}$ neurons $(6.3 \pm 0.9 \mathrm{mV} ; n=7)$ with an increase in input resistance $(12.1 \pm 4.9 \% ; n=7$; Fig. $4 B)$. This finding suggests that $\mathrm{K}_{\mathrm{ATP}}$ channels are activated under basal conditions and probably contribute to the resting $\mathrm{K}^{+}$conductance and so the membrane potential of this cell type. Because 2/AH neurons contain other channel types, including $\mathrm{Ca}^{2+}$ activated $\mathrm{K}^{+}$channels (Furness et al., 1998), the involvement of multiple channels sensitive to tolbutamide remains to be determined.

\section{Glucoresponsive enteric neurons are hyperpolarized by the KATP channel opener diazoxide and leptin}

The $\mathrm{K}_{\mathrm{ATP}}$ channel opener selected for this study, diazoxide, was chosen because it is the most effective of the $\mathrm{K}^{+}$channel openers at activating the $\beta$-cell and $\mathrm{VMH}$ neuron $\mathrm{K}_{\mathrm{ATP}}$ channel (Dunne et al., 1989; Lee et al., 1999). Concentrations used were comparable with those used by other investigators and found to be effective in opening $\mathrm{K}_{\mathrm{ATP}}$ channels (Watts et al., 1995). An initial removal of glucose was used to determine whether the cell was glucoresponsive. Cells that were not hyperpolarized by the removal of glucose were not studied further, because a preliminary investigation revealed that these cells also failed to respond to diazoxide $(n=5)$.

The hyperpolarization produced by removal of glucose from the bath solution was mimicked by diazoxide $(300 \mu \mathrm{M})$ (Trube et al., 1986) in nine of nine glucoresponsive $2 / \mathrm{AH}$ and three of three $1 / \mathrm{S}$ neurons studied (Fig. $5 A$ ). Superfusion of diazoxide produced a significant increase in $\operatorname{RMP}(7.2 \pm 1.2 \mathrm{mV} ; n=9 ; p<0.05)$, which reached maximal amplitude within $10 \pm 0.1 \mathrm{~min}$ after application. In contrast, similar applications of the $\mathrm{K}_{\mathrm{ATP}}$ channel opener pinacidil $(n=3 ; 500 \mu \mathrm{M})$ failed to evoke a significant hyperpolarization. The diazoxide-induced hyperpolarization was accompanied by a significant decrease in input resistance of $19.5 \pm 4.4 \%(n=9 ; p<0.001)$. Current-voltage relations in 2/AH neurons before and after diazoxide application (Fig. $5 B$ ) showed that the conductance increase had a reversal potential of $-82 \pm 3 \mathrm{mV}(n=3)$, indicating an increase in potassium current.

Diazoxide induced a greater hyperpolarization in a glucosefree solution (Fig. 5D). In five glucoresponsive 2/AH neurons, diazoxide hyperpolarized the membrane potential from $-58.0 \pm$ 2.1 to $-64.7 \pm 1.7 \mathrm{mV}$. In a glucose-free solution, diazoxide hyperpolarized the membrane from $-63.1 \pm 3.3$ to $-72.2 \pm 2.8$ $\mathrm{mV}$. One explanation of the greater effect of diazoxide in a glucose-free solution is that in the presence of glucose, the intracellular ATP concentration was high enough to prevent the complete opening of $\mathrm{K}_{\mathrm{ATP}}$ channels by diazoxide (Trube et al., 1986). In a glucose-free solution, the intracellular ATP concentration within the cell was reduced to levels at which the $\mathrm{K}_{\mathrm{ATP}}$ channels could open spontaneously.

To determine whether the effects of diazoxide were caused by the activation of $\mathrm{K}_{\mathrm{ATP}}$ channels, we examined the effects of tolbutamide. Bath application of tolbutamide $(500 \mu \mathrm{M})$ com- 
(A) , Tolbutamide $(500 \mu \mathrm{M})$ in 0 glucose $12.7 \mathrm{mM}$
glucose

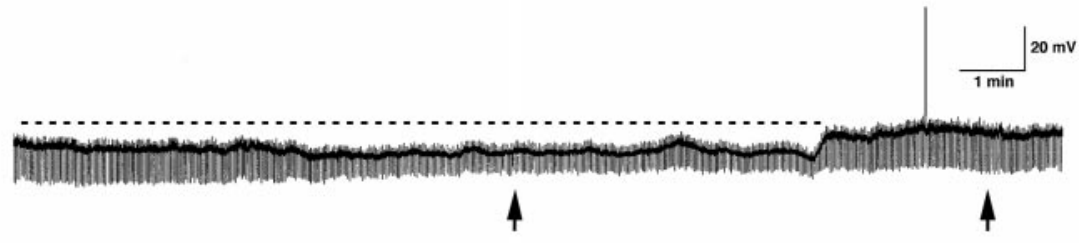

(B)

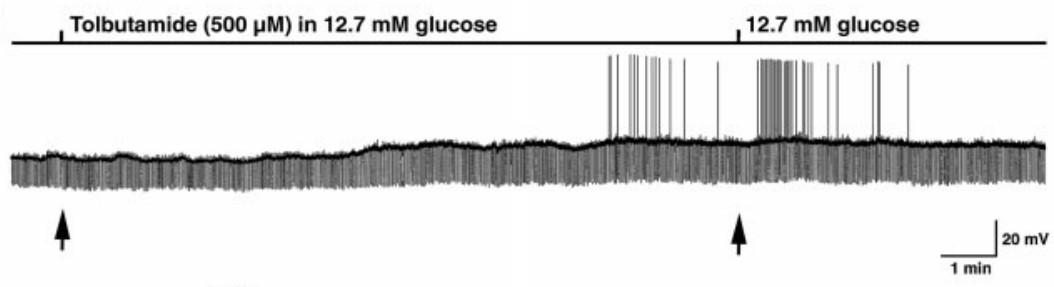

(C)

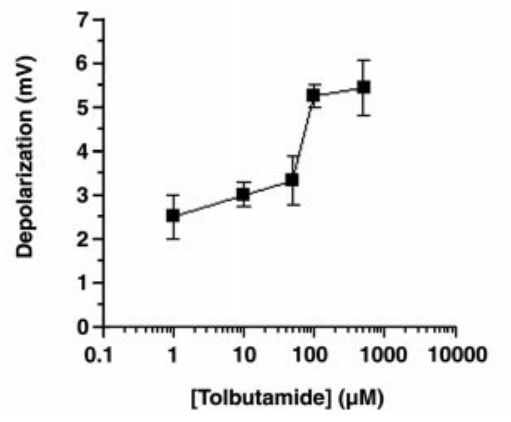

Figure 4. Glucoresponsive enteric neurons are sensitive to tolbutamide. $A$, Current-clamp recording from a $2 / \mathrm{AH}$ neuron shows that reducing the glucose concentration from 12.7 to $0 \mathrm{~mm}$ induced hyperpolarization and decreased input resistance. Subsequent application of tolbutamide $(500 \mu \mathrm{M})$ reversed these actions and induced spike activity. $B$, Superfusion of tolbutamide $(500 \mu \mathrm{M})$ in a glucose-containing (12.7 $\mathrm{mM})$ solution induced a membrane depolarization and spike activity in a 2/AH neuron. $C$, Summary of the concentration dependence of tolbutamidemediated depolarizations is shown. Data are expressed as amplitude changes of the maximum control response $(n=6)$. RMPs (dashed line in $A$ ) were -55 $\mathrm{mV}(A)$ and $-72 \mathrm{mV}(B)$. pletely reversed the membrane hyperpolarization and increase in conductance to prediazoxide levels $(n=5$; Fig. $5 C)$. The inhibitory effects of tolbutamide were reversible on washout. These data are in agreement with that of studies using $\beta$-cells (Dunne et al., 1989) and VMH neurons (Lee et al., 1999) and indicate that these actions of diazoxide are attributable to the activation of $\mathrm{K}_{\text {ATP }}$ channels.

Activation of pre- or postsynaptic $\mathrm{K}_{\mathrm{ATP}}$ channels or both could

(A)

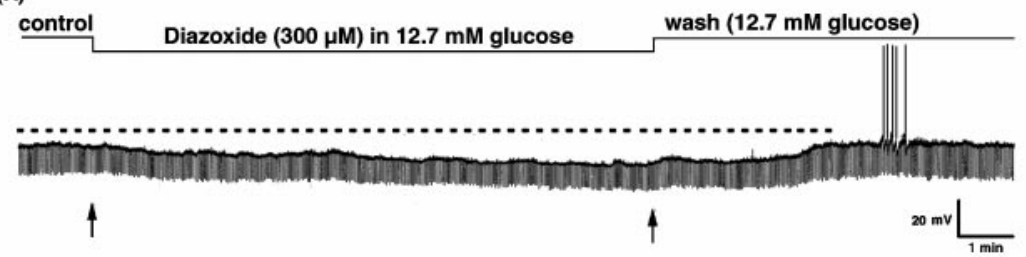

(B) Current (nA)

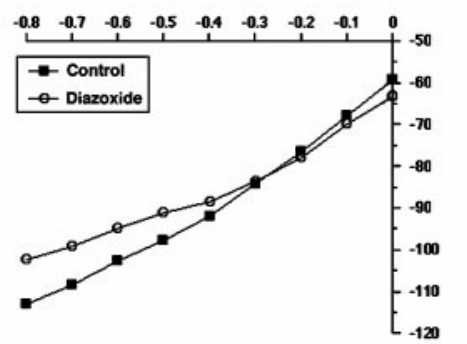

(D)

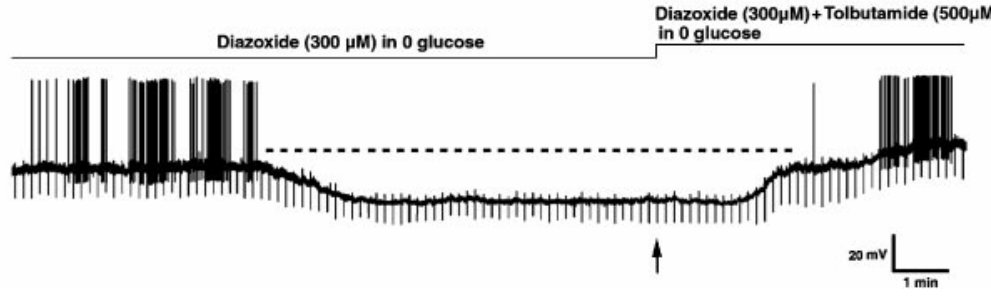

(C)

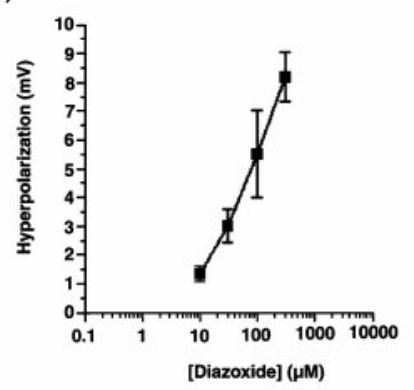

Figure 5. Diazoxide hyperpolarizes glucoresponsive enteric neurons via activation of $\mathrm{K}_{\mathrm{ATP}}$ channels. $A$, Currentclamp recording from a $2 / \mathrm{AH}$ neuron shows that superfusion of diazoxide $(300 \mu \mathrm{M})$ for the time indicated resulted in hyperpolarization of the membrane from -60 to $-71 \mathrm{mV}$ and that the action readily reversed on washout. $B$, Currentvoltage plot for the currents obtained in the presence of glucose (12.7 mM; control) and diazoxide is shown. The mean reversal potential associated with the increase in conductance was $-82 \mathrm{mV}$. $C$, Summary of the concentration dependence of diazoxide-mediated hyperpolarizations is shown. Data are expressed as amplitude changes of the maximum control response $(n=6)$. $D$, The effects of diazoxide and no-glucose on RMP and input resistance are reversed by tolbutamide $(500 \mu \mathrm{M})$. RMPs (dashed lines) were $-60 \mathrm{mV}(A)$ and $-66 \mathrm{mV}(D)$. 
(A)

Leptin $\quad$ Wash

(B)

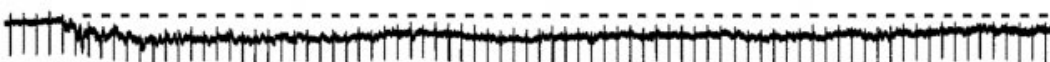

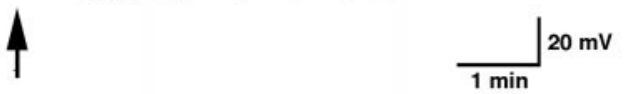

\begin{tabular}{l|l} 
Leptin & Wash
\end{tabular}

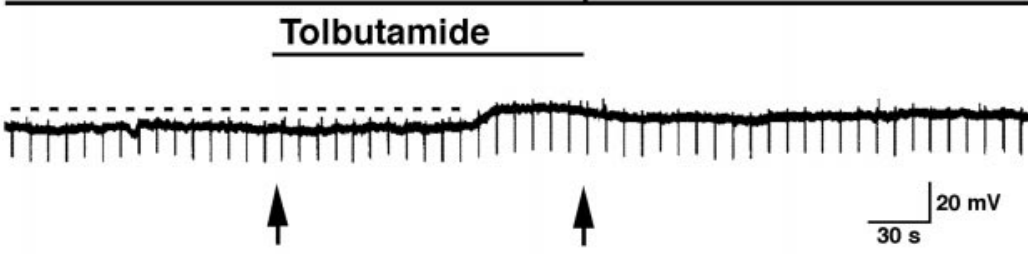

(C)

Figure 6. Leptin hyperpolarizes glucoresponsive enteric neurons via activation of $\mathrm{K}_{\mathrm{ATP}}$ channels. $A$, Current-clamp recording from a $2 / \mathrm{AH}$ neuron shows that superfusion of leptin ( $20 \mathrm{~nm})$ for the time indicated resulted in hyperpolarization of the membrane from -46 to $-55 \mathrm{mV}$ and that the action slowly reversed as leptin was washed out of the bath. $B$, The effects of leptin are reversed by tolbutamide $(500$ $\mu \mathrm{M}) . C$, Current-voltage plot for the currents obtained in the presence of glucose $(12.7 \mathrm{mM}$; control $)$ and leptin is shown. The mean reversal potential associated with the increase in conductance was -85 $\mathrm{mV}$. RMPs (dashed lines) were $-46 \mathrm{mV}(A)$ and $-50 \mathrm{mV}(B)$.

potentially account for hyperpolarizing responses to diazoxide. To examine the locus of diazoxide-induced hyperpolarizations, we analyzed the response in the presence of TTX or low $\mathrm{Ca}^{2+}$ / high $\mathrm{Mg}^{2+}$ solutions. Neither TTX (300 nM; $\left.n=4\right)$ nor low $\mathrm{Ca}^{2+} /$ high $\mathrm{Mg}^{2+}(0.1 \mathrm{~mm} / 15.0 \mathrm{~mm} ; n=3)$ solutions significantly affected hyperpolarizing responses to diazoxide in 2/AH neurons. In the presence of low $\mathrm{Ca}^{2+} /$ high $\mathrm{Mg}^{2+}, 2 / \mathrm{AH}^{2}$ neurons exhibited $\mathrm{Ca}^{2+}$ spikes because these cells contain $\mathrm{Ca}^{2+}$-activated $\mathrm{K}^{+}$ channels; however, in the three neurons, diazoxide induced a significant hyperpolarization from $-62.0 \pm 2.5 \mathrm{mV}$ before diazoxide exposure to $-71.7 \pm 2.7 \mathrm{mV}$ after diazoxide. These data indicate that the hyperpolarizing response to diazoxide is not caused by the release of another neurotransmitter but is directly mediated by diazoxide-responsive channels on the impaled neuron.

Similar to diazoxide, superfusion of the adipocyte-derived hormone leptin (10-15 nM) evoked a slow and progressive hyperpolarization of glucoresponsive $2 / \mathrm{AH}$ neurons that resulted in a new equilibrium 5-15 min after application (Fig. 6A). The mean RMP of 2/AH neurons before and 15 min after leptin application was $-56.2 \pm 3.4$ and $-60.1 \pm 3.3 \mathrm{mV}$, respectively, with a mean peak hyperpolarization of $4.0 \pm 1.3 \mathrm{mV}(n=11 ; p<0.05)$. The leptin-evoked hyperpolarization was accompanied by a decrease in input resistance of $14.3 \pm 2.6 \%(n=11)$. Current-voltage relations before and after leptin application showed that the conductance increase had a reversal potential of $-85 \mathrm{mV}$, indicating an increase in potassium current (Fig. $6 C$ ). This was caused by the opening of $\mathrm{K}_{\mathrm{ATP}}$ channels as tolbutamide $(500 \mu \mathrm{M})$ re-
Current (nA)

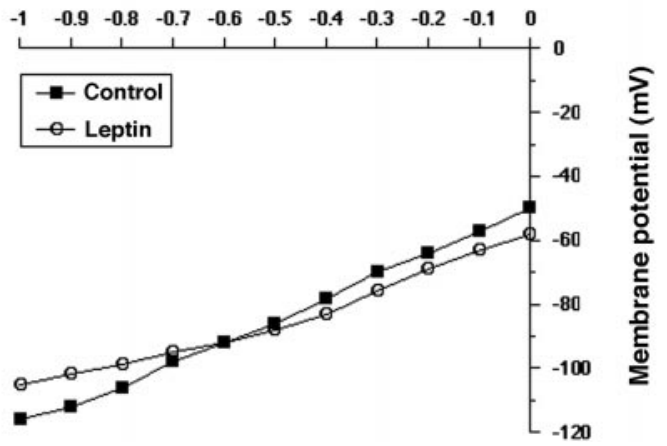

versed the effects of this hormone, inducing depolarization and an increased input resistance (Fig. 6B). In the presence of tolbutamide and leptin, glucoresponsive neurons often reached threshold for action potential firing. Removal of tolbutamide allowed the leptin response to reemerge, even though the leptin was also washed out of the bath. In nonglucoresponsive neurons (that is, neurons insensitive to a reduction of extracellular glucose concentration), leptin (10-100 nM) had no effect on RMP $(n=4)$ or induced a $2-8 \mathrm{mV}$ depolarization (in nine neurons). A depolarizing response to leptin has been observed in neurons of the paraventricular nucleus of the hypothalamus and appears to be caused by the activation of a nonspecific cation channel (Powis et al., 1998). The mechanism underlying the response in the gut remains to be determined.

\section{Glucoresponsive enteric neurons express leptin receptors}

To confirm that glucoresponsive enteric neurons express leptin receptors, we examined the distribution of LepR immunoreactivity in the guinea pig ENS. After experiments in which the effects of leptin (and no-glucose) on the electrical properties of myenteric neurons were studied, impaled neurons were marked by injection of Neurobiotin to ascertain whether the cell from which recordings were obtained actually expressed leptin receptors. Neurons that responded to leptin with a hyperpolarizing response (marked by the intracellular injection of Neurobiotin) displayed LepR immunoreactivity (Fig. 7A,B).

As observed in the CNS (Diano et al., 1998; Hakansson et al., 

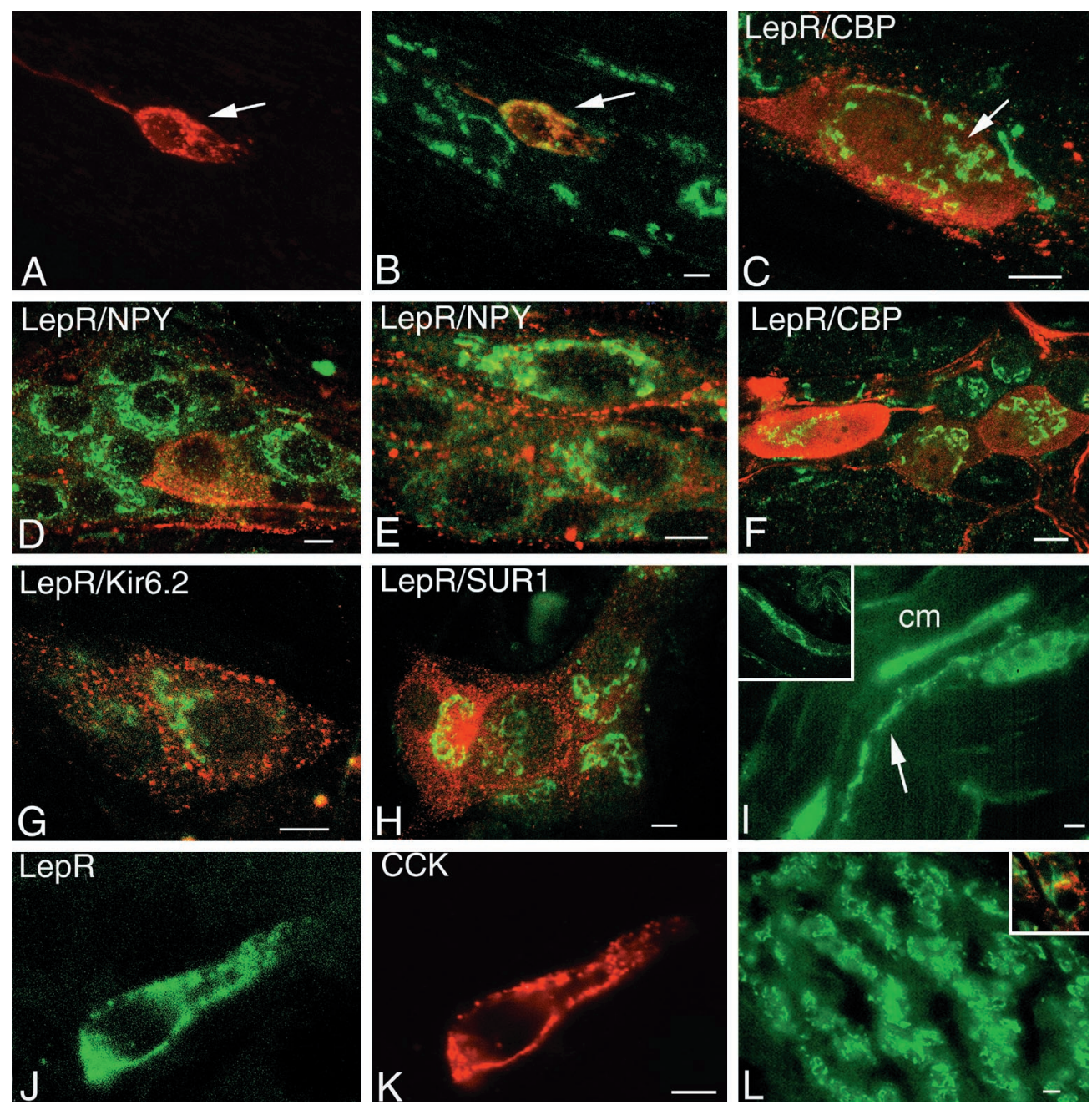

Figure 7. Distribution of leptin receptor immunoreactivity in the guinea pig ileum. $A, B$, Leptin-responsive enteric neurons display leptin receptor immunoreactivity. A leptin-responsive 2/AH neuron was marked by intracellular injection of Neurobiotin (A; arrow). The leptin-responsive 2/AH neuron displays leptin receptor immunoreactivity $(B$; $a r-$ row). Neurobiotin was visualized with avidin-Cy3 (red). Leptin receptor immunoreactivity was visualized with FITC (green). $C$, Leptin receptor immunoreactivity (green) appears to be localized to the Golgi complex of CBP-immunoreactive myenteric neurons (red; arrow). $D-F$, Leptin receptor immunoreactivity (green) is displayed by NPY-immunoreactive submucosal neurons $(D ;$ red $)$ and CBP-immunoreactive myenteric neurons $(F$; red $)$. NPY-immunoreactive nerve fibers (red) encircle myenteric neurons that express leptin receptors $(E$; green $)$. $G, H$, Leptin receptor immunoreactivity (green) is expressed by all Kir6.2 $(G)$ and SUR1 $(H)$-immunoreactive neurons in the submucosal plexus; however, more neurons express leptin receptor immunoreactivity than $\mathrm{K}_{\mathrm{ATP}}$ channels. $I$, Leptin receptor immunoreactivity (green) is found on nerve fibers in the circular muscle layer and in the region of the deep muscular plexus (inset). In the latter region, immunoreactivity appears to be associated with the interstitial cells of Cajal. $J-L$, Leptin receptor immunoreactivity $(J$; green $)$ is displayed by CCKcontaining enteroendocrine cells in the mucosa $(K ; \mathrm{red})$ and islet cells $(L)$ that coexpress insulin (red; $L$, inset). $A-L$ are confocal images. Scale bars: $A-F, 30 \mu \mathrm{m}$; $G-L, 10 \mu \mathrm{m}$.
1998), LepR immunoreactivity in permeabilized whole-mount preparations of enteric neurons appeared to be primarily associated with the Golgi apparatus, suggesting a high level of leptin receptor synthesis (Fig. 7C). All NPY- and ChAT-immunoreactive submucosal neurons displayed LepR immunoreactivity (Fig. 7D), and numerous NPY-immunoreactive boutons were in close apposition to the perikaryal membrane of myenteric neurons that contained LepR (Fig. 7E). Together, these data indicate that both NPY-producing cells and the postsynaptic targets of NPY axons express LepR. All calbindin-immunoreactive neurons displayed LepR immunoreactivity (Fig. $7 F$ ), supporting our data that leptin affects the activity of 2/AH neurons (see above). LepR immunoreactivity was also displayed by both Kir6.2 (Fig. $7 G$ )- and SUR1 (Fig. $7 H$ )-immunoreactive neurons, providing further support for the idea that a subset of enteric neurons may be able to monitor fat and glucose stores.

LepR immunoreactivity was also found on structures located outside of enteric ganglia. Within the ileum, punctate LepR immunoreactivity was displayed by nerve fibers in the circular muscle layer (Fig. 7I) and on cells identified as interstitial cells of Cajal, by virtue of their expression of c-Kit immunoreactivity (Fig. 7I, inset). Furthermore, endocrine cells in the intestinal mucosa displayed LepR immunoreactivity. Because these cells were found to contain 5-HT and/or CCK (Fig. 7J,K), they are probably enteroendocrine cells. Endocrine cells in the guinea pig pancreas displayed LepR immunoreactivity (Fig. $7 L$ ). In fact, all insulin-immunoreactive islet cells expressed LepR, similar to rats.

\section{Diazoxide inhibits fast synaptic transmission}

Because both hypoglycemia and diazoxide have been shown to inhibit electrically induced contractions of the guinea pig small intestine (Zini et al., 1991; Corbett and Lees, 1997), mediated, at least in part, via the inhibition of acetylcholine (ACh) release, experiments were conducted to determine whether diazoxide affected fast EPSPs in enteric neurons. The majority of neurons in guinea pig myenteric ganglia exhibit nicotinic fast EPSPs in response to stimulation of interganglionic nerve bundles (Galligan and Bertrand, 1994; Liu et al., 1997). Data were obtained from $1 / \mathrm{S}$ neurons, because these cells were observed to exhibit fast EPSPs with the highest frequency.

Fast synaptic events were evoked by stimulating interganglionic nerve bundles $(0.2 \mathrm{~Hz} ; 0.5 \mathrm{msec} ; 1-10 \mathrm{~V})$ with the cell current clamped to $-90 \mathrm{mV}$ by injection of negative direct current (Liu et al., 1997). After obtaining a fast EPSP, diazoxide $(300 \mu \mathrm{M})$ was superfused (10 $\mathrm{min}$ ), and the response was again elicited. Diazoxide caused a $26.4 \pm 5.2 \%$ reduction in the fast EPSP amplitude (control, $14.8 \pm 1.3 \mathrm{mV}$; diazoxide, $11.1 \pm 1.4 \mathrm{mV} ; p<0.05$; $n=6$; Fig. $8 A$ ). The amplitude of fast EPSPs was also significantly reduced by the nicotinic antagonist hexamethonium $(100 \mu \mathrm{M}$; to $15.0 \pm 9 \%$ of control; $n=5$ ), indicating that the response was 
(A)
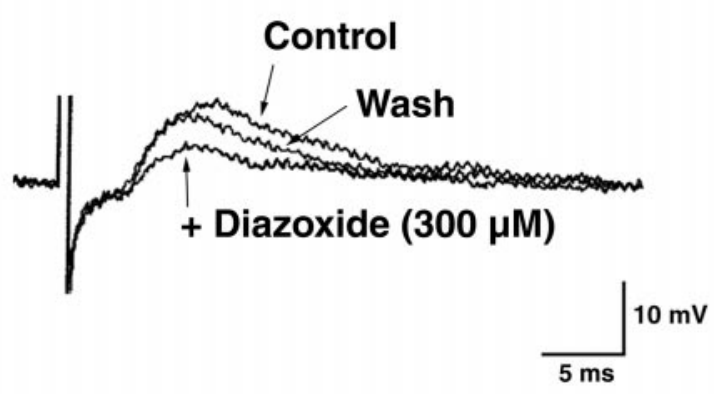

(B)

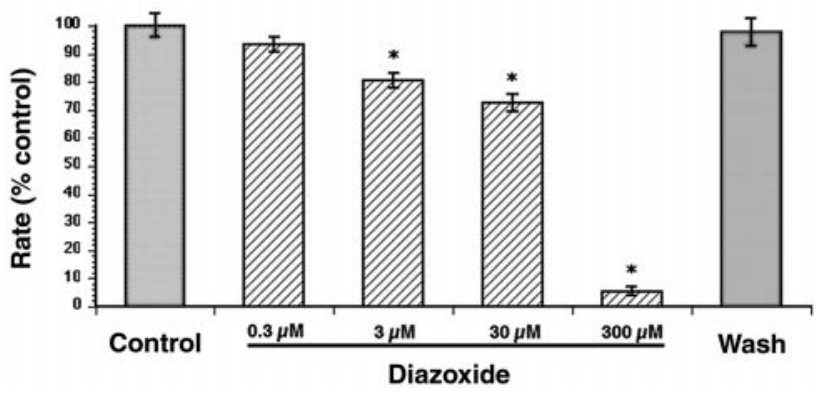

Figure 8. Diazoxide inhibits fast synaptic transmission and colonic motility. $A$, Fast EPSPs in $1 / \mathrm{S}$ neurons were elicited by fiber tract stimulation before (Control) and during diazoxide superfusion and after washout (Wash) of the $\mathrm{K}_{\mathrm{ATP}}$ channel opener. The amplitude of the fast EPSP was significantly reduced by the application of diazoxide in all cells studied. RMP was $-80 \mathrm{mV}$. $B$, Diazoxide dose dependently inhibits the propulsion of an artificial fecal pellet in the isolated guinea pig colon.

mediated by the release of ACh. To determine whether diazoxide was acting presynaptically to suppress the fast EPSP, we tested the effect of diazoxide on the responsiveness of $2 / \mathrm{AH}$ neurons to microejection of nicotine $(1 \mu \mathrm{M})$. The responsiveness of neurons to nicotine was not significantly altered by diazoxide (control, $9.2 \pm 1.5 \mathrm{mV}$; diazoxide, $8.3 \pm 2.1 \mathrm{mV} ; n=4$ ); therefore, diazoxide probably acts presynaptically to suppress nicotinic fast synaptic transmission.

\section{Diazoxide inhibits colonic motility}

If activation of presynaptic $\mathrm{K}_{\mathrm{ATP}}$ channels by diazoxide inhibits the release of $\mathrm{ACh}$, as the above observations imply, then diazoxide should interfere with the peristaltic reflex because it is dependent, at least in part, on nicotinic pathways (Foxx-Orenstein and Grider, 1996; Wade et al., 1996). The effects of diazoxide on the reflex-initiated rate of propulsion of an artificial fecal pellet in the guinea pig distal colon were therefore determined to test this hypothesis.

As observed previously (Foxx-Orenstein and Grider, 1996; Wade et al., 1996), the rate of propulsion of artificial fecal pellets was constant for segments obtained from the same colon. Incubation of colonic segments with TTX $(0.5 \mu \mathrm{M} ; n=4)$ abolished the reflex, indicating that it was nerve-mediated (data not shown). In addition, the reflex was also inhibited by incubation with diazoxide (Fig. $8 B$ ). Incubation of the segments for $10 \mathrm{~min}$ with diazoxide $(0.3-300 \mu \mathrm{M})$ caused a concentration-dependent inhibition of the rate of propulsion. Propulsion was abolished by 300 $\mu \mathrm{M}$. The observation that diazoxide abolishes reflex-driven propulsion indicates that enteric $\mathrm{K}_{\mathrm{ATP}}$ channels are functional and that activation of these channels inhibits motility.

\section{DISCUSSION}

The aim of this study was to determine whether the ENS contains neurons that are sensitive to glucose. Intracellular recordings revealed that a subset of neurons in the guinea pig myenteric plexus responds to changes in extracellular glucose concentration with an alteration in electrical behavior. Two kinds of glucosereceptive neurons were identified. Glucoresponsive neurons were excited by increases in extracellular glucose. Removal of extracellular glucose resulted in hyperpolarization of these cells, which was accompanied by a decrease in input resistance and the inhibition of spontaneous firing. Glucosensitive neurons were excited by decreases in extracellular glucose. They represented approximately half of the myenteric neurons that responded to changes in the extracellular glucose concentration.

Glucoresponsive and glucosensitive neurons are found in the VMH and lateral hypothalamus (LH) (Oomura et al., 1974), respectively. In general, manipulations of the $\mathrm{VMH}$ and $\mathrm{LH}$ produce opposite effects on food intake and autonomic function. The $\mathrm{LH}$ region is a source of output signals that instruct the animal to eat and release insulin. As a meal progresses, the $\mathrm{VMH}$ sends out satiety signals that generally inhibit these parasympathetic functions (Leibowitz and Hoebel, 1998). The demonstration of two types of glucose-receptive neurons in the ENS suggests that they too may play opposite roles in the regulation of gut function. Increases in extracellular glucose concentration would preferentially excite glucoresponsive neurons and inhibit glucosensitive cells. This would result in the selective activation of specific microcircuits during periods of hyperglycemia.

The change in resting membrane potential and input resistance of glucoresponsive neurons in response to alterations in extracellular glucose level was concentration dependent. In the presence of low glucose (0.0-5.0 mm), the cells were hyperpolarized, and spontaneous spike activity disappeared. As the concentration of glucose was increased, the neurons became depolarized, and spontaneous spike activity reappeared. Thus, the excitability of glucoresponsive neurons is determined by the extracellular glucose concentration. This may explain why acute changes in the blood glucose concentration have a substantial effect on gastrointestinal motor reflexes (MacGregor et al., 1976) and visceral sensation (Lingenfelser et al., 1999). Although it has been assumed that the gastrointestinal motor symptoms and alterations in gut sensations observed in patients with diabetes mellitus were part of a generalized autonomic neuropathy, they may actually be produced by changes in the activity of enteric neurons. By directly affecting the excitability of enteric neurons, changes in blood glucose concentration could modulate gut motility, secretion, and/or sensory transduction.

The hyperpolarization of glucoresponsive neurons evoked by low glucose involved the activation of a $\mathrm{K}^{+}$conductance because it was associated with a decrease in neuronal input resistance, and the reversal potential correlated with $\mathrm{E}_{\mathrm{K}}$. Because the sulfonylurea tolbutamide completely reversed the hyperpolarization evoked by removal of glucose, the response is likely to involve the activation of $\mathrm{K}_{\mathrm{ATP}}$ channels. A tolbutamide-sensitive hyperpolarization and increase in $\mathrm{K}^{+}$conductance were produced by application of diazoxide and the ob gene product leptin. Both diazoxide and leptin activate $\mathrm{K}_{\mathrm{ATP}}$ channels in VMH neurons (Spanswick et al., 1997; Lee et al., 1999) and CRI-G1 insulinsecreting cells (Harvey et al., 1997; Harvey and Ashford, 1998b), although the mechanism underlying their actions appears to differ. Diazoxide is likely to act directly on SUR1, which acts as a 
regulator of channel activity. Leptin activation of $\mathrm{K}_{\mathrm{ATP}}$ channels appears to involve inhibition of tyrosine kinases and subsequent dephosphorylation of as yet unidentified proteins (Harvey and Ashford, 1998a). Glucoresponsive enteric neurons displayed leptin receptor immunoreactivity, suggesting sensitivity to fat stores. There is increasing evidence that a feedback loop exists between adipose tissue and the excitability of glucose-sensitive cells (Mizuno et al., 1996). Thus, the ENS is a potential target of leptin's action.

The subunit composition of a $\mathrm{K}_{\mathrm{ATP}}$ channel determines the conductance, the blocking potency of ATP, and the pharmacological profile of the channel. Thus, $\mathrm{K}_{\mathrm{ATP}}$ channels of $\beta$-cells, which are composed of Kir6.2 and SUR1 subunits (Inagaki et al., 1995a), are sensitive to ATP, diazoxide, and tolbutamide, whereas $\mathrm{K}_{\mathrm{ATP}}$ channels of heart and skeletal muscle, which are composed of Kir6.2 and SUR2A, are sensitive to ATP, pinacidil, and glibenclamide, but not to diazoxide (Inagaki et al., 1996; Seino, 1999). Glucoresponsive neurons in the ENS are sensitive to both tolbutamide and diazoxide. Furthermore, a decrease in $[\mathrm{ATP}]_{\mathrm{i}}$ probably activates enteric $\mathrm{K}_{\mathrm{ATP}}$ channels, because a hyperpolarization was produced by the metabolic inhibitor sodium azide. Thus, it is reasonable to propose that the $\mathrm{K}_{\mathrm{ATP}}$ channels in enteric neurons are a complex composed of Kir6.2 and SUR1. In support of this hypothesis, a subset of enteric neurons displayed Kir6.2 and SUR1 immunoreactivity.

Kir6.2- and SUR1-immunoreactive neurons costored ChAT, and a subset also contained SP and calbindin immunoreactivities. The submucosal SP- and ChAT- and SP-, ChAT-, and calbindinimmunoreactive neurons, which also contain glutamate (Liu et al., 1997), are thought to be primary afferent neurons that carry information from the intestinal lumen to submucosal and myenteric ganglia (Kirchgessner et al., 1992). Although these neurons constitute only a small subset $(\sim 10 \%)$ of the neurons in the submucosal plexus, they are critical for orchestrating the coordination of motility and secretion (Cooke, 1998) and are essential for the initiation of peristaltic activity (Gershon et al., 1994). The myenteric ChAT- and calbindin-immunoreactive neurons are also thought to be primary afferent neurons (Furness et al., 1998), because the projections of this type of cell are compatible with such a role and the neurons are activated by chemical stimulation of the mucosa (Bertrand et al., 1997).

The expression of $\mathrm{K}_{\mathrm{ATP}}$ channel proteins by intrinsic primary afferent neurons suggests that $\mathrm{K}_{\mathrm{ATP}}$ channels may play a role in sensory transduction. Activation of $\mathrm{K}_{\mathrm{ATP}}$ channels has been shown to inhibit the release of SP from extrinsic sensory nerve endings (Ohkubo and Shibata, 1995). $\mathrm{K}_{\mathrm{ATP}}$ channels are found in the mucosa; therefore, it is possible that glucose excites primary afferent neurons by closing $\mathrm{K}_{\mathrm{ATP}}$ channels located on nerve terminals within the lamina propria. This would depolarize the cell and cause the stimulation of second-order neurons in the submucosal and/or myenteric plexus that control secretion and/or motility. It is also possible that $\mathrm{K}_{\mathrm{ATP}}$ channels are present on extrinsic afferents; however, whether or not these channels are present in dorsal root and/or nodose ganglion neurons merits further investigation.

In addition to postsynaptic $\mathrm{K}_{\mathrm{ATP}}$ channels, it also appears likely that enteric neurons contain presynaptic $\mathrm{K}_{\mathrm{ATP}}$ channels that are responsible for the inhibition of fast EPSPs. It has been suggested previously that the gut contains presynaptic $\mathrm{K}_{\mathrm{ATP}}$ channels (Zini et al., 1991) and that activation of these channels inhibits the release of $\mathrm{ACh}$ and decreases contraction of the smooth muscle. $\mathrm{K}_{\mathrm{ATP}}$ channel-like immunoreactivity was displayed by ChAT- immunoreactive nerve fibers in the circular muscle layer; therefore, $\mathrm{K}_{\mathrm{ATP}}$ channels appear to be present on cholinergic nerve terminals in the muscle. The decrease in ACh release produced by activation of presynaptic $\mathrm{K}_{\mathrm{ATP}}$ channels may explain the inhibition in colonic motility produced by diazoxide. The peristaltic reflex depends on cholinergic transmission (Kadowaki et al., 1996); therefore, drugs that inhibit the release of $\mathrm{ACh}$ are likely to affect motility.

The presence of $\mathrm{K}_{\mathrm{ATP}}$ channels in the ENS has several important implications. Mutations in SUR1 result in persistent hyperinsulinemic hypoglycemia of infancy (PHHI), a disease associated with unregulated insulin secretion (Thomas et al., 1995) attributable to a loss of $\mathrm{K}_{\mathrm{ATP}}$ channel activity in $\beta$-cells (Dunne et al., 1995). Patients with PHHI commonly suffer from debilitating gastrointestinal side effects (Aynsley-Green and Hawdon, 1997) of unknown etiology. The presence of SUR1 in the ENS suggests that mutations in this receptor are likely to result in a loss of $\mathrm{K}_{\mathrm{ATP}}$ channel activity in enteric neurons. This would be expected to depolarize the cell chronically, an effect that could produce excitotoxicity (Kirchgessner et al., 1997). It is also well established that $\mathrm{K}_{\mathrm{ATP}}$ channels are activated in abnormal situations such as anoxia and ischemia, when cellular ATP concentrations decline. Intestinal ischemia is common in inflammatory bowel disease, especially Crohn's disease, which probably results from multifocal intestinal infarction (Pounder, 1994). There is evidence that ischemia depresses neuroeffector transmission in the gut (Corbett and Lees, 1997). The defects caused by ischemia could be produced by changes in neuronal activity via the modulation of neuronal $\mathrm{K}_{\mathrm{ATP}}$ channel activity. The development of drugs that could preferentially target either pre- or postsynaptic $\mathrm{K}_{\mathrm{ATP}}$ channels in the ENS would be of tremendous value in elucidating the functions of these channels in gut physiology.

In summary, we have identified neurons in the ENS that appear to sense changes in extracellular glucose levels via $\mathrm{K}_{\mathrm{ATP}}$ channel activity. We propose that the pharmacological and molecular biological properties of this channel are essentially the same as those found for the $\mathrm{K}_{\mathrm{ATP}}$ channel complex in the pancreatic $\beta$-cell. In future studies it will be important to examine the physiological and pathophysiological modulation of this channel complex.

\section{REFERENCES}

Aguilar-Bryan L, Nichols CG, Wechsler SW, Clement JP, Boyd AE, Gonzalez H, Herrera-Sosa H, Nguy K, Bryan J, Nelson DA (1995) Cloning of the $\beta$-cell high-affinity sulphonylurea receptor: a regulator of insulin secretion. Science 268:423-425.

Anand BK, Brobeck JR (1951) Hypothalamic control of food intake in rats and cats. Yale J Biol Med 24:123-140.

Ashcroft FM, Harrison DE, Ashcroft SJH (1984) Glucose induces closure of single potassium channels in isolated rat pancreatic cells. Nature 312:446-448.

Ashcroft SH, Ashcroft FM (1990) Properties and functions of ATPsensitive $\mathrm{K}^{+}$channels. Cell Signal 2:197-214.

Ashford MLJ, Boden PR, Treherne JM (1990a) Glucose-induced excitation of hypothalamic neurones is mediated by ATP-sensitive $\mathrm{K}^{+}$ channels. Pflügers Arch 415:479-483.

Ashford MLJ, Boden PR, Treherne JM (1990b) Tolbutamide excites rat glucoreceptive ventromedial hypothalamic neurones by indirect inhibition of ATP-K ${ }^{+}$channels. Br J Pharmacol 101:531-540.

Aynsley-Green A, Hawdon JM (1997) Hypoglycemia in the neonate: current controversies. Acta Paediatr Jpn 39[Suppl 1]:S12-S16.

Bertrand PP, Kunze WAA, Bornstein JC, Furness JB, Smith ML (1997) Analysis of the responses of myenteric neurons in the small intestine to chemical stimulation of the mucosa. Am J Physiol 273:G422-G435.

Calabresi P, Ascone CM, Centonze D, Pisani A, Sancesario G, D’Angelo V, Bernardi G (1997) Opposite membrane potential changes induced 
by glucose deprivation in striatal spiny neurons and in large aspiny interneurons. J Neurosci 17:1940-1949.

Cook DL, Hales CN (1984) Intracellular ATP directly blocks K+ channels in pancreatic cells. Nature 311:271-273.

Cooke HJ (1998) "Enteric tears": chloride secretion and its neural regulation. News Physiol Sci 13:269-274.

Corbett AD, Lees GM (1997) Depressant effects of hypoxia and hypoglycemia on neuro-effector transmission of guinea-pig intestine studied in vitro with a pharmacological model. Br J Pharmacol 120:107-115.

Costa M, Brookes SJH, Steele PA, Gibbins I, Burcher E, Kandiah CJ (1996) Neurochemical classification of myenteric neurons in the guinea-pig ileum. Neuroscience 75:949-967.

Dean PM, Matthews EK, Sakamoto Y (1975) Pancreatic islet cells: effects of monosaccharides, glycolytic intermediates and metabolic inhibitors on membrane potential and electrical activity. J Physiol (Lond) 246:459-478

Diano S, Kalra SP, Horvath TL (1998) Leptin receptor immunoreactivity is associated with the Golgi apparatus of hypothalamic neurones and glial cells. J Neuroendocrinol 10:647-650.

Dunne MJ, Yule DI, Gallacher DV, Petersen OH (1989) Cromakalim (BRL34915) and diazoxide activate ATP-regulated potassium channels in insulin-secreting cells. Pflügers Arch 414 [Suppl 1]:S154-S155.

Dunne MJ, Kane C, Squires PE, Lindley KJ, Johnson PRV, James RFL (1995) Persistent neonatal hyperinsulinaemic hypoglycemia involves a defect in pancreatic $\beta$-cell $\mathrm{K}^{+}$channels. J Physiol (Lond) 489:7S.

Foxx-Orenstein AE, Grider JR (1996) Regulation of colonic propulsion by enteric excitatory and inhibitory neurotransmitters. Am J Physiol 271[Gastrointest Liver Physiol 34]:G433-G437.

Furness JB, Kunze WAA, Bertrand PP, Clerc N, Bornstein JC (1998) Intrinsic primary afferent neurons of the intestine. Prog Neurobiol $54: 1-18$.

Galligan JJ, Bertrand PP (1994) ATP mediates fast synaptic potentials in enteric neurons. J Neurosci 14:7563-7571.

Gershon MD, Kirchgessner AL, Wade PR (1994) Functional anatomy of the enteric nervous system. In: Physiology of the gastrointestinal tract, Third Edition (Johnson LR, ed), pp 381-422. New York: Raven.

Grundy D, Scratcherd T (1989) Sensory afferent from the gastrointestinal tract. In: Handbook of physiology, Sec 6, Vol 1 (Schultz SG, Wood JD, Rauner BB, eds), pp 593-620. New York: Oxford UP.

Hakansson M-L, Brown H, Ghilardi N, Skoda RC, Meister B (1998) Leptin receptor immunoreactivity in chemically defined target neurons of the hypothalamus. J Neurosci 18:559-572.

Harvey J, Ashford MLJ (1998a) Role of tyrosine phosphorylation in leptin activation of ATP-sensitive $\mathrm{K}^{+}$channels in the rat insulinoma cell line CRI-G1. J Physiol (Lond) 510:47-61.

Harvey J, Ashford MLJ (1998b) Diazoxide- and leptin-activated $\mathrm{K}_{\text {ATP }}$ currents exhibit differential sensitivity to englitazone and ciclazindol in the rat CRI-G1 insulin-secreting cell line. $\mathrm{Br} \mathrm{J}$ Pharmacol 124:1557-1565.

Harvey J, McKenna F, Herson PS, Spanswick D, Ashford MLJ (1997) Leptin activates ATP-sensitive potassium channels in the rat insulinsecreting cell line, CRI-G1. J Physiol (Lond) 504:527-535.

Horvath TL, Diano S, van den Pol AN (1999) Synaptic interaction between hypocretin (orexin) and neuropeptide Y cells in the rodent and primate hypothalamus: a novel circuit implicated in metabolic and endocrine regulations. J Neurosci 19:1072-1087.

Inagaki N, Gonoi T, Clement JP, Namba N, Inazawa J, Bryan L, Gonzalez G, Aguilar-Bryan L, Seino S, Bryan J (1995a) Reconstruction of I KATP: an inward rectifier subunit plus the sulfonylurea receptor. Science 270:1166-1170.

Inagaki N, Tsuura Y, Namba N, Masuda K, Gonoi T, Horie M, Seino Y, Miauta M, Seino S (1995b) Cloning and functional characterization of a novel ATP-sensitive potassium channel ubiquitously expressed in rat tissues including pancreatic islets, pituitary, skeletal muscle, and heart. J Biol Chem 270:5691-5694.

Inagaki N, Gonoi T, Clement JP, Wang CZ, Aguilar-Bryan L, Bryan J, Seino S (1996) A family of sulfonylurea receptors determines the properties of ATP-sensitive $\mathrm{K}^{+}$channels. Neuron 16:1011-1017.

Inui A (1999) Feeding and body-weight regulation by hypothalamic neuropeptides-mediation of the actions of leptin. Trends Neurosci 22:62-67.

Iyer V, Bornstein JC, Costa M, Furness JB, Takahashi Y, Iwanaga T (1988) Electrophysiology of guinea-pig myenteric neurons correlated with immunoreactivity for calcium binding proteins. J Auton Nerv Syst 22:141-150.
Jiang C, Haddad GG (1992) Differential responses of neocortical neurons to glucose and/or $\mathrm{O} 2$ deprivation in human and rat. J Neurophysiol 68:103-111.

Kadowaki M, Wade PR, Gershon MD (1996) Participation of 5-HT $5-\mathrm{HT}_{4}$, and nicotinic receptors in the peristaltic reflex of guinea pig distal colon. Am J Physiol 271:G849-G857.

Keiffer TJ, Heller RS, Leech CA, Holz GG, Habener JF (1997) Leptin suppression of insulin secretion by the activation of ATP-sensitive $\mathrm{K}^{+}$ channels in pancreatic beta cells. Diabetes 46:1087-1093.

Kirchgessner AL, Gershon MD (1988) Projections of submucosal neurons to the myenteric plexus of the guinea pig intestine: in vitro tracing of microcircuits by retrograde and anterograde transport. J Comp Neurol 277:487-498.

Kirchgessner AL, Liu M-T (1998) Immunohistochemical localization of nicotinic acetylcholine receptors in the guinea pig bowel and pancreas. J Comp Neurol 390:497-514.

Kirchgessner AL, Liu M-L (1999) Differential localization of $\mathrm{Ca}^{2+}$ channel $\alpha 1$ subunits in the enteric nervous system: presence of $\alpha_{1 \mathrm{~B}}$ channel-like immunoreactivity in intrinsic primary afferent neurons. J Comp Neurol 409:85-104.

Kirchgessner AL, Tamir H, Gershon MD (1992) Identification and stimulation by serotonin of intrinsic sensory neurons of the submucosal plexus of the guinea pig gut: activity-induced expression of Fos immunoreactivity. J Neurosci 12:235-249.

Kirchgessner AL, Liu M-T, Gershon MD (1996) In situ identification and visualization of neurons that mediate enteric and enteropancreatic reflexes. J Comp Neurol 371:270-286.

Kirchgessner AL, Liu M-T, Alcantara F (1997) Excitotoxicity in the enteric nervous system. J Neurosci 17:8804-8816.

Komuro T, Zhou DS (1996) Anti-c-kit protein immunoreactive cells corresponding to the interstitial cells of Cajal in the guinea-pig small intestine. J Auton Nerv Syst 61:169-174.

Lee K, Dixon AK, Richardson PJ, Pinnock RD (1999) Glucosereceptive neurones in the rat ventromedial hypothalamus express $\mathrm{K}_{\mathrm{ATP}}$ channels composed of Kir6.1 and SUR1 subunits. J Physiol (Lond) $515: 439-452$.

Leibowitz SF, Hoebel BG (1998) Behavioral neuroscience of obesity. In: Handbook of obesity (Bray GA, Bouchard C, James WPT, eds), pp 313-358. New York: Dekker.

Lingenfelser T, Sun W-M, Hebbard GS, Dent J, Horowitz M (1999) Effects of duodenal distension on antropyloroduodenal pressure and perception are modified by hyperglycemia. Am J Physiol 276:G711-G718.

Liu MT, Rothstein J, Gershon MD, Kirchgessner A (1997) Glutamatergic enteric neurons. J Neurosci 17:4764-4784.

MacGregor IL, Gueleer R, Watts HD, Meyer JH (1976) The effect of acute hyperglycemia on gastric emptying in man. Gastroenterology 70:190-196.

Matthews EK (1985) Electrophysiology of pancreatic islet $\beta$-cells. In: The electrophysiology of the secretory cell, Vol 2, Chap 4 (Poisner AM, Trifaro JM, eds). Amsterdam: Elsevier.

Mei N (1978) Vagal glucoreceptors in the small intestine of the cat. J Physiol (Lond) 282:485-506.

Mizuno TM, Bergen H, Funabashi T, Kleopoulos SP, Zhong YG, Bauman WA, Mobbs CR (1996) Obese gene expression-reduction by fasting and stimulation by insulin and glucose in lean mice, and persistent elevation in acquired (diet-induced) and genetic (yellow agouti) obesity. Proc Natl Acad Sci USA 93:3434-3438.

Ohkubo T, Shibata M (1995) ATP-sensitive $\mathrm{K}^{+}$channels mediate regulation of substance $\mathrm{P}$ release via the prejunctional histamine $\mathrm{H}_{3}$ receptor. Eur J Pharmacol 277:45-49.

Oomura Y (1983) Glucose as a regulator of neuronal activity. Adv Metab Disord 10:31-65.

Oomura Y, Ooyama H, Sugimori M, Nakamura T, Yamada Y (1974) Glucose inhibition of the glucose-sensitive neurone in the rat lateral hypothalamus. Nature 247:284-286.

Pounder RE (1994) The pathogenesis of Crohn's disease. J Gastroenterol 29:11-15.

Powis JE, Bains JS, Ferguson AV (1998) Leptin depolarizes rat hypothalamic paraventricular nucleus neurons. Am J Physiol 274:R1468-R1472.

Raybould HE, Zittel TT (1995) Inhibition of gastric motility induced by intestinal glucose in awake rats: role of $\mathrm{Na}(+)$-glucose co-transporter. Neurogastroenterol Motil 7:9-14.

Rorsman P, Trube G (1985) Glucose dependent $\mathrm{K}^{+}$channels in pancre- 
atic cells are regulated by intracellular ATP. Pflügers Arch 405:305-309.

Sakura H, Ammala C, Smith PA, Gribble FM, Ashcroft FM (1995) Cloning and functional expression of the cDNA encoding a novel ATP-sensitive potassium channel subunit in pancreatic $\beta$-cells, brain, heart and skeletal muscle. FEBS Lett 377:338-344.

Schutte IWM, Kroese ABA, Akkermans LMA (1995) Somal size and location within the ganglia for electrophysiologically identified myenteric neurons of the guinea pig ileum. J Comp Neurol 355:563-572.

Seino S (1999) ATP-sensitive potassium channels: a model of heteromultimeric potassium channel/receptor assemblies. Annu Rev Physiol 61:337-362.

Spanswick D, Smith MA, Groppi VE, Logan SD, Ashford MLJ (1997) Leptin inhibits hypothalamic neurons by activation of ATP-sensitive potassium channels. Nature 390:521-525.

Suzuki M, Fujikura K, Inagaki N, Seino S, Takata T (1997) Localization of the ATP-sensitive $\mathrm{K}^{+}$channel subunit Kir6.2 in mouse pancreas. Diabetes 46:1440-1444.
Thomas PM, Cote GJ, Wohllk N, Haddad B, Mathew PM, Rabl W, Aguilar-Bryan L, Gagel RF, Bryan J (1995) Mutations in the sulphonylurea receptor gene in familial persistent hyperinsulinemic hypoglycemia of infancy. Science 268:425-429.

Trube G, Rorsman P, Ohno-Shosaku T (1986) Opposite effects of tolbutamide and diazoxide on the ATP-dependent $\mathrm{K}+$ channel in mouse pancreatic $\beta$ cells. Pflügers Arch 407:493-499.

Wade PR, Chen J, Jaffe B, Kassem IS, Blakely RD, Gershon MD (1996) Localization and function of a 5-HT transporter in crypt epithelia of the gastrointestinal tract. J Neurosci 16:2352-2364.

Watts AE, Hicks GA, Henderson G (1995) Putative pre- and postsynaptic ATP-sensitive potassium channels in the rat substantia nigra in vitro. J Neurosci 15:3065-3074.

Zini S, Ben-Ari Y, Ashford MLJ (1991) Characterization of sulfonylurea receptors and the action of potassium channel openers on cholinergic neurotransmission in guinea pig isolated small intestine. J Pharmacol Exp Ther 259:566-573. 